\title{
Koruma Amacıyla Özgürlüğün Kısıtlanması Kurumunun Ağır Tehlike Arz Eden Salgın Hastalık Hali Bakımından Elverişliliğinin Değerlendirilmesi
}

\author{
Nil Karabağ Bulut $\odot$
}

Öz

Türk Medeni Kanunu'nda bir vesayet tedbiri olarak düzenlenmiş olan koruma amacıyla özgürlüğün kısıtlanması kurumu, kişisel korumaya ihtiyaç duyan gerçek kişilerin TMK m 432 hükmünde sayılan şartlarla belirli bir kuruma zorla yerleştirilmelerini veya belirli bir kurumda zorla alıkonulmalarını düzenlemektedir. Özgürlüğün belirli bir kuruma yerleştirilmek veya orada alıkonulmak amacıyla kısıtlanması, kişinin ihtiyaç duyduğu kişisel korumanın sağlanması amacına yöneliktir. Bir kişinin özgürlüğünün bu şekilde kısıtlanması, koruma ihtiyacının TMK m 432 hükmünde sayılan zayıfık halleri dolayısıyla ortaya çıkmış olmasına bağlıdır. Türk Hukuku’na ilk defa 4721 sayılı Türk Medeni Kanunu ile girmiş olan bu tedbir, vesayet hükümleri arasında yer almakla birlikte, uygulanması için öngörülen şartlar itibariyle, ilgili kişinin korunmasından ziyade toplumun korunmasına hizmet edecek şekilde düzenlenmiştir. Kanun koyucu, TMK m 432 hükmünde sayılan zayıflık halleri dolayısıyla ortaya çıkan koruma ihtiyacının karşılanmasını, ilgili kişinin toplum için tehlike oluşturması şartına bağlamış görünmektedir. Bunun yanı sıra, hükümde sayılan zayıflık hallerinden ağır tehlike arzeden bulaşıcı hastalık dolayısıyla kişi özgürlüğünün kısıtlanması, başlı başına toplumun korunması amacına hizmet etmektedir. Kanun koyucu, koruma amacıyla özgürlüğün kısıtlanmasına ilişkin hükümler arasında zorla tedaviye yer vermemiştir. Özellikle, korunma ihtiyacının ayırt etme gücünün bulunmaması dolayısıyla ortaya çıkmış olduğu hallerde zorla tedavi, kısa sürede kişinin korunma ihtiyacının ortadan kalkmasını sağlayabilecektir. Kanun koyucunun TMK m 432 vd hükümlerinde bu yönde bir düzenleme getirmemiş olması, ayırt etme gücü olmayan kişilerin ömür boyu bir kurumda kalmaları sonucunu doğurabilecektir. Buraya kadar ifade edilen sebepler, koruma amacıyla özgürlüğün kısıtlanması kurumunun vesayet kurumu ile öngörülen amaçlara uygun bir şekilde, özellikle şartları itibariyle yeniden düzenlenmesini gerektirmektedir. Çalışmanın amacı, TMK m 432 hükmü kapsamında öngörülmüş olan şartların, bu açıdan değerlendirilmesidir.

\section{Anahtar Kelimeler}

Vesayet, Koruma amacıyla özgürlüğün kısıtlanması, Kişi hürriyeti, Zorla tedavi, Ağır tehlike arzeden bulaşıcı hastalık

Considerations on the Conditions Provided for the Restriction of Freedom for the Purposes of Protection due to an extremely dangerous Infectious Disease

\begin{abstract}
The institution of restriction of freedom for the purposes of protection is regulated as a guardian-ship measure under the Turkish Civil Code (TCC), and under conditions specified in Article 432 of TCC, it allows compulsory placement or detainment in a certain establishment of individuals in need of personal protection. Restriction of freedom by compulsory placement/detainment in a particular establishment aims to protect the relevant individual needs. Such restriction requires the need for protection to arise from the causes of weakness listed under Article 432 of TCC. This measure, which was first introduced into Turkish Law by the TCC numbered 4721, is regu-lated within the guardianship provisions;
\end{abstract}

* Sorumlu Yazar: Nil Karabağ Bulut (Dr. Öğr. Üyesi), İstanbul Üniversitesi, Hukuk Fakültesi, Medeni Hukuk Anabilim Dalı, İstanbul, Türkiye. E-posta: nkarabag@istanbul.edu.tr ORCID: 0000-0001-6996-4228

Atıf: Karabag-Bulut N, “Koruma Amacıyla Özgürlüğün Kısıtlanması Kurumunun Ağır Tehlike Arz Eden Salgın Hastalık Hali Bakımından Elverişliliğinin Değerlendirilmesi" (2020) 78(2) İstanbul Hukuk Mecmuası 517. https://doi.org/10.26650/mecmua.2020.78.2.0010 
however, it serves for the protection of the society ra-ther than the protection of the person concerned due to its conditions of implementation. It seems that the legislator stipulates the protection for instances where the person concerned also poses a threat to society. Furthermore, restriction of freedom due to an extremely dangerous in-fectious disease serves, in itself, the purpose of protecting society. Implementation of forced treatment is not regulated under these provisions even though forced treatment is a feasible method to overcome the need for protection specifically when this need is due to lack of mental capacity. The absence of provisions regarding forced treatment may result in lifelong detainment of individuals who lack mental capacity. The reasons stated so far reveals that the institution of restriction of freedom for protection and, in particular, its conditions for implementation must be revised following the objectives of the guardianship institution. Hence, this study aims to evalu-ate the conditions set forth under Article 432 of TCC within this context.

\section{Keywords}

Guardianship, Restriction of freedom for the purposes of protection, Freedom of person, Forced treatment, Extremely dangerous infectious disease

\section{Extended Summary}

Certain conditions of restriction of freedom for protection that are regulated are incorporated from Article 19/II of the Turkish Constitution, which aims to provide the legal basis of preventive measures under Article 432 of the Turkish Civil Code (TCC). Hence, mental disorder, mental disability, alcohol and drug addiction, extremely dangerous infectious disease, and vagrancy are specified in line with Article 19 of the Constitution. Nevertheless, Article 432 of TCC is a measure of deputyship that solely aims for the protection of personality. The preventive measures are intended for the protection of public health and safety. Therefore, interpretation of the conditions provided by Article 432 of TCC must be carried out bearing in mind its nature of deputyship measure.

One of the grounds for the restriction of freedom for protection set forth by Article 432 of TCC is "extremely dangerous infectious disease." The restriction of freedom based on a serious infectious disease aims to protect the public. Inclusion of extremely dangerous infectious disease to Article 432 aims to prevent the spread of the disease; therefore, the purpose is to protect the public. Thus, the measure in question holds a just cause and pursues maintaining public safety, particularly public health. The spread of the disease to this extent not only endangers the health of individuals but also has adverse effects, primarily on the healthcare system and also on other areas such as economy and education, thus causing living conditions to be oppressive. Consequently, recent outcomes of the coronavirus disease 2019 (Covid-19) pandemic have demonstrated the necessity of implementing such a provision.

However, the application of forced treatment is beyond the scope of Article 432 of TCC, and the desired protection cannot be achieved through this provision. In case of serious infectious disease, Article 432 lacks legal legitimacy for the protection of public health. This provision excludes forced treatment, even under the assumption that individual protection is linked to treatment. 
Moreover, the restriction of freedom for protection as per Article 432 requires a decision issued by the court of deputyship. However, any delay arising from this requirement would only cause further spreading of the disease during a pandemic such as Covid-19. In such a case, there is a public interest in isolating the patient without requiring a court order. For reasons explained thus far, the prevention of the spread of an extremely dangerous infectious disease cannot be maintained by implementing the deputyship measure of the restriction of freedom for protection. In other words, instances of extremely dangerous infectious disease should be removed from the scope of the relevant provision.

Furthermore, the Public Healthcare Law numbered 1593, dated April 24, 1930, is still in force under Turkish law. To enable the implementation of immediate measures, the aforementioned law needs modernization. In addition, a balance needs to maintained between the limited interest for the protection of freedom of infected or suspected patients and the elimination of extremely dangerous infectious diseases considering public interest. Therefore, the principle of proportionality should be applied regarding isolation and forced treatment, and general principles and rules of implementation concerning forced treatment should be thoroughly regulated.

The condition of potential "endangering of the society" is also required for the application of the said measure in addition to the instances of the need for individual protection specified under the provision. This additional condition is only suitable in relation to the implementation of extremely dangerous infectious disease from among the instances listed under Article 432. Therefore, the conditions of "endangering the society" and the "extremely dangerous infectious disease" should both be removed from Article 432 TCC. The restriction of freedom for protection serves to protect those who need protection for certain reasons and is regulated under the institution of "deputyship." The judge should rule in issues concerning the application of Article 432 of TCC bearing in mind the purpose of the deputyship institution. The condition of endangering the society should be interpreted narrowly and must only be applied to instances of extremely dangerous infectious disease taking into account the purpose of the relevant provision. In line with the principle regulated under Article 23 of the TCC where personal rights of an individual are also protected against his or her actions, the application of such a measure should a fortiori be allowed in instances where the focus of protection is the individual himself or herself. This is the case while bearing in mind that forced placement or detainment is possible even for the purposes of public protection. 


\section{Koruma Amacıyla Özgürlüğün Kısıtlanması Kurumunun Ağır Tehlike Arz Eden Salgın Hastalık Hali Bakımından Elverişliliğinin Değerlendirilmesi}

\section{Giriş}

Koruma amaciyla özgürlüğün kısıtlanması, bir gerçek kişinin, TMK m 432 hükümlerinde sınırlı sayıda düzenlenmiş olan belirli sebeplerle ihtiyaç duyduğu kişisel korunmanın sağlanması amacıyla iradesi hilafina belirli bir kuruma yerleştirilmesi veya bulunduğu kurumda alıkonulmasıdır. Bir vesayet tedbiri olarak öngörülmüş olan koruma amacıyla özgürlüğün kısıtlanması, ilgili kişinin hürriyetinin sınırlanmasına yol açmaktadır.

Kişi hürriyeti ve güvenliği, AY m 19 hükmü ile koruma altına alınmıştır. Söz konusu hükümle, herkesin kişi hürriyeti ve güvenliğine sahip olduğu ifade edildikten sonra, ikinci fikra hükmünde, kişi hürriyetinin kısıtlanmasının şartları öngörülmüştür. $\mathrm{Bu}$ kapsamda; "toplum için tehlike oluşturan akıl hastası, uyuşturucu madde veya alkol tutkunu, serseri veya hastalı yayabilecek bir kişsinin bir müessesede tedavi, eğitim veya ıslahı için kanunda belirtilen esaslara uygun olarak alınan tedbirin yerine getirilmesi”, kişi hürriyetinin sınırlandırılmasına yol açabilecek istisnalardandır. Ancak AY m 19/II hükmü, söz konusu sınırlandırmanın esaslarının bir kanun hükmünde tayin edilerek gerçekleştirilmesini emretmiştir. Bu başlık altında inceleyeceğimiz TMK m 432 vd hükümlerinin, AY m 19/II hükmünde düzenlenmiş olan tedbirler bakımından hukuki dayanak oluşturduğu ifade edilmektedir ${ }^{1}$.

Kişi özgürlügü ve güvenliği, ayrıca Avrupa İnsan Hakları Sözleşmesi kapsamında da koruma görmektedir. Herkesin özgürlük ve güvenlik hakkına sahip olduğunu düzenleyen AİHS m 5/I hükmü, bu hakların sınırlandırılmasını mümkün kılan bir takım haller öngörmüştür. İlgili düzenleme de söz konusu hakların sınırlandırılmasının esaslarının mutlaka kanun ile düzenlenmiş olması şart koşulmuştur. Bu kapsamda m 5 hükmünün (e) bendi uyarınca; "Bulaşıcı hastalıkların yayllmasını engellemek amacıyla, hastalı̆̆l yayabilecek kişilerin, akıl hastalarının, alkol veya uyuşturucu madde bağımlılarının veya serserilerin yasaya uygun olarak tutulması," mümkün görülmüştür.

Kanun koyucu, ilk defa 4721 sayılı Türk Medeni Kanunu m 432 vd hükümleri ile özgürlüğün, kişinin kendisini koruma amacıyla sınırlandırılmasına imkân veren

\footnotetext{
Ahmet M Kılıçoğlu, Aile Hukuku (4. Bası, Turhan 2019). 586. Turgut Akıntürk ve Derya Ateş, Türk Medeni Hukuku, Aile Hukuku, C 2 (22. Bası, Beta 2020) 505; Ayrıca bkz 4721 sayılı Kanun'un gerekçesi, s. 456: "Bu kurum İsviçre Medeni Kanunda 1 Ocak 1981 tarihinde yürürlüğe girmiş olan yeni düzenlemeden esinlenmek suretiyle Ülkemiz için de geçerli olduğu düşüncesiyle yeni bir ayrım olarak kanuna alınmıştır. Nitekim aynı ihtiyaç Anayasa'nın 19 uncu maddesinde de açıkça ifade edilmiştir", Türk Medeni Kanunu Tasarısı ile Türk Kanunu Medenisinde Değişiklik Yapılması Hakkında Kanun Tasarısı ve Ankara Milletvekili Yücel Seçkiner'in; Ankara Milletvekili Esvet Özdoğu ve Dört Arkadaşının; Aynı Kanunda Değişiklik Yapılması Hakkında Kanun Teklifleri ve Adalet Komisyonu Raporu (1/611, 1/425, 2/361, 2/680), https://www.tbmmgov.tr/sirasayi/donem21/yil01/ss723mhtm Erişim Tarihi 9 Mayıs 2020.
} 
“Koruma Amacıyla Özgürlüğün Kısıtlanması” kurumunu düzenlemiştir². Söz konusu düzenlemelerin İsviçre Medeni Kanunu'nun 387a ila 397f maddelerinden ${ }^{3}$ yola ç1k1larak oluşturulduğu, 22 Kasım 2011 tarihli ve 4721 sayılı Türk Medeni Kanunu'nun gerekçesinde açıkça ifade edilmiştir. Buna göre; “...Yürürlükteki Kanunda ve 1984 tarihli Öntasarıda mevcut olmayan bu altıncı ayırım, İsviçre Medenî Kanununda 1 Ocak 1981 tarihinde yürürlüğe girmiş bulunan yeni düzenlemeden esinlenerek ve aynı düzenlemenin Ülkemiz için de gerekli ve yararlı olduğu düşünce ve inancıyla Tasarıya alınmıştır. Nitekim aynı ihtiyaç Anayasamızın 19 uncu maddesinde de açıça ifade edilmiştir"'4.

Kanun koyucu, koruma amacıyla özgürlüğün sınırlanması kurumunu düzenlerken, her ne kadar o tarihte yürürlükte olan İMK. m 397a vd hükümlerinden yola çıkıldığını ifade etse de, TMK m 432 vd hükümleri ile mülga İMK. m 397a vd hükümleri arasında önemli nitelikte farklılıklar bulunmaktadır. Aşağıda ayrıntılı şekilde inceleneceği üzere, kanun koyucu, koruma amaciyla özgürlüğün k1sıtlanmasının şartlarını düzenleyen TMK m 432 hükmünün AY m 19/II hükmü ile bire bir uyumlu olmasına özen göstermiştir.

Bununla birlikte, AY m 19/II hükmü ile ilgili Danışma Meclisi’nin gerekçesinden açıkça anlaşıldığı üzere5, kanun koyucu, AY m 19/II hükmü ile "önleyici güvenlik tedbirleri” bakımından düzenleme getirmeyi amaçlamıştır. Gerekçeye göre; “(...) Bilindiği gibi suçla savaşta etkili olunabilmesi için suçun işlenmesini beklememek; suç işlemeye fevkalade müsait bir düzey üstünde bulunan kişiler hakkında, zamanında uygun tedbirler alarak zararı daha kaynă̆ında önlemek gerekir. "Suç öncesi safha" denilen bu safhada bulunan kişiler özellikle, uyuşturucu madde tutkunları, alkolikler, akıl hastaları yahut serserilerdir.......Kolayca anlaşılacă̆l gibi akıl hastası, uyuşturucu madde tutkunu yahut alkoliğin veya yukarıda ifade edildiği anlamda bir serserinin suç işleme ihtimali, diğer kişilerin gösterdiği riskten daha yüksektir. Bunlar kendi hallerine bırakıldıkları takdirde toplum için devamlı bir tehlike ve tehdit teşkil edeceklerdir. Kendilerinin bir adım daha atarak suç alanına girmelerine engel olmak için kendileri

4721 sayılı Türk Medeni Kanunu'nun yürürlüğe girmesinden önce kişilerin ihtiyaç duyduğu kişisel korumanın sağlanması amacıyla başvurulan yasal düzenlemeler hakkında ayrıntılı bilgi için bkz Mehmet Dağlı, Emsal İçtihatlarla Türk Medeni Hukukunda Koruma Amactyla Özgürlüğ̈̈̈ Kısttlanması (Turhan 2011) 3 vd.

3 Koruma amacıyla özgürlüğün kısıtlanması, İsviçre Medeni Kanunu’na 6 Ocak 1978 tarihli Kanun ile eklenmiş olup, 1 Ocak 1981 tarihinde yürürlüğe girmiştir. İsviçre kanun koyucusu, söz konusu hükümlerin düzenlenmesinde Avrupa İnsan Hakları Sözleşmesi m 5 hükmünden yola çıkmıştır. Bkz Eugen Spirig, 'Art 397a-397f' in Peter Gauch, Jörg Schmid (eds) Kommentar zum Schweizerischen Zivilgesetzbuch, Das Familienrecht, 3. Abteilung: Die Vormundschaft (Art 360-456), Band II, Nummer $3 a$ (Schulthess1995) Vorb zu Art 397a-397f, N 35. Bununla birlikte ilgili hükümler, vesayet kurumunun yeniden düzenlenmesi amacıyla sevk edilen 19 Aralık 2008 tarihli Kanun kapsamında önemli değişikliklere uğramıştır. Söz konusu Kanun ile getirilen değişiklikler, 1 Ocak 2013 tarihinde yürürlüğe girmiştir. Bkz 19 Aralık 2008 tarihli Kanun Gerekçesi, BBI 20067003 vd (https://www.admin.ch/opc/de/federal-gazette/2006/7001.pdf Erişim Tarihi 2 Mayıs 2020).

4 "Türk Medeni Kanunu Tasarısı ile Türk Kanunu Medenisinde Değişiklik Yapılması Hakkında Kanun Tasarısı ve Ankara Milletvekili Yücel Seçkiner'in; Ankara Milletvekili Esvet Özdoğu ve Dört Arkadaşının; Aynı Kanunda Değişiklik Yapılması Hakkında Kanun Teklifleri ve Adalet Komisyonu Raporu (1/611, 1/425, 2/361, 2/680)”, https://www.tbmmgov.tr/sirasayi/ donem21/yil01/ss723mhtm Erişim Tarihi 9 Mayıs 2020.

5 Bkz Madde Gerekçeli Türkiye Cumhuriyeti Anayasası, TBMM, 2008, (<https://acikerisimtbmmgov.tr/xmlui/bitstream/ handle/11543/1169/200901027.pdf?sequence=1\&isAllowed=y > Erişim Tarihi 12 Mayıs 2020). 
konusunda "Önleyici güvenlik tedbirleri" yahut, diğer bir deyimle, "Toplumsal savunma tedbirleri" alnmaktadır. Bu tedbirlerin neler olduğu, uygulama şartlart ve benzeri hususlar, bugün pekçok ülkede kabul edilmiş bulunan "Toplumsal Savunma Kanunlarl" tarafindan düzenlenecektir. Bu tür tedbirlerin bazllarının (müessesede eğitim) uygulanmasl, "Tehlikeli hal" gösteren kişinin şu veya bu şekilde kısıtlanmasını zorunlu kılar. İzahına çalışılan hüküm bu ihtiyacı karşılamaktadır".

Kanun koyucunun vesayet tedbiri olan "Koruma Amaciyla Özgürlüğün Kısıtlanması" kurumunu düzenlerken, ”önleyici güvenlik tedbirleri” bakımından düzenleme getirmeyi hedefleyen AY m 19/II hükmüne ilişkin metnin ilgili kısmını olduğu gibi benimsemiş olması, kurum ile güdülen amaca ulaşılmasını önemli derecede engelleyebilecek nitelikte bir düzenleme getirilmesine yol açmıştır. Çalışmamızda güdülen amaç, koruma amacıyla özgürlüğün kısıtlanması kurumunun şartlarını düzenleyen TMK m 432 hükmünün vesayet tedbiri olması sebebiyle, ifa etmesi gereken işleve ne denli uygun olduğunun incelenmesidir.

Bunun yanı sıra, TMK m 432 vd hükümlerinin düzenlenmesinde kaynak olarak dikkate alındığı ifade edilen mülga İMK. m 397a vd hükümleri, vesayet kurumunda önemli değiş̧iklikler getiren 19 Aralık 2008 tarihli Kanun ile İsviçre Medeni Kanunu m 426 vd hükümlerinde yeniden düzenlenmiştir. İsviçre Kanun koyucusu, revizyon sonucunda "Koruma Amaciyla Özgürlüğün Kısıtlanması" kavramı yerine, "Koruma Amacıyla Yerleştirme" kavramını tercih etmiştir. Söz konusu değişikliklerin özgürlüğü kısıtlanacak olan kişiye daha güçlü bir hukuki koruma sağlanabilmesi ve düzenlemelerde yer alan boşlukların doldurulması amacıyla getirildiği ifade edilmiştir ${ }^{6}$. Çalışmada söz konusu değişikliklere de kısaca yer verilecektir.

\section{Koruma Amacıyla Özgürlüğün Kısıtlanması Kurumunun Amacı}

Koruma amacıyla özgürlüğün kısıtlanması kurumunun amacının tayini bakımından, söz konusu tedbirin Medeni Kanun'da yer aldığı bölüm, büyük önem arz eder. Kanun koyucu, ilgili düzenlemeye 'Aile Hukuku' başlıklı ikinci kitabın 'Vesayet' başlıklı üçüncü kısmında yer vermiş̧ir. Vesayet, kişisel ve malvarlıksal menfaatlerini koruma yetkinliğinden yoksun olan kimselerin korunması için öngörülmüş olan hukuki bir kurumdur ${ }^{7}$. Bu kapsamda velayet altında olmayan kişilerin korunması hedeflenmektedir. Vesayetin devlet tarafından teşkilatlandırılmış olması, bu kurumu, özel hukukun yanı sıra kamu hukukunun sinırlarına da sokmaktadır. Bu halde koruma amacıyla özgürlüğün kısıtlanması kurumunun hem özel hukukun hem de kamu hukukunun alanına giren karma bir niteliğe sahip olduğunu söylemek yanlış olmaz

\footnotetext{
Bkz 19 Aralık 2008 tarihli Kanun Gerekçesi, BBI 20067003 vd (https://www.admin.ch/opc/de/federal-gazette/2006/7001. pdf Erişim Tarihi 2 Mayıs 2020).

7 Tanım için bkz Bilge Öztan, Aile Hukuku (6. Bası, Turhan 2015) 1257; Nevzat Koç, ‘Türk Medenî Kanunundaki Düzenlemeler Işı̆̆ında Vesayet Hukukuna Genel Bakış’, (2005) VII ( ) Dokuz Eylül Üniversitesi Hukuk Fakültesi Dergisi 99.

8 Ayrıntılı bir inceleme için bkz Spirig (n 3) Vorb zu Art 397a-397f, N 26 vd; Öztan (n 7) 1257.
} 
Vesayet kapsamında koruma gören kişiler, öncelikle fiil ehliyeti sınırlandırılmış olan kişilerdir. Kanun koyucu, fiil ehliyetini emredici hükümlerle düzenlemiştir. Fiil ehliyeti, bir kimsenin kendi fiiliyle hak edinebilmesi ve borç altına girebilmesini ifade etmektedir'. Hak ehliyetinde olduğu gibi, herkesin fiil ehliyetine sahip olduğunu söylemek mümkün değildir ${ }^{10}$. Kanun koyucu, bir kişinin fiil ehliyetine sahip olduğunun kabulü için ayırt etme gücü, erginlik ve kısıtlı olmama şartlarını aramıştır (TMK m 10). Bu şartları haiz bir kişi, fiil ehliyetine sahip olup, tam ehliyetli olarak nitelendirilir ${ }^{11}$. Ayırt etme gücünün bulunmadığı haller bakımından ise kişinin tam ehliyetsiz olmasından söz edilir ${ }^{12}$. Buna karşılık ayırt etme gücünü haiz küçükler ve kısıtllar ise sınırlı ehliyetsiz olarak nitelendirilmektedirler ${ }^{13}$. Bu hali ile her bir şartın eksikliğinin fiil ehliyetinin farklı nitelikte sınırlandırılmasına yol açtığını söyleyebiliriz. Fiil ehliyetinin varlığının kabulü için bulunması gereken şartlardan hangisinin eksik olduğuna göre farklı kategoriler yaratılmış olmasının bir sebebi, söz konusu kişilerin kişisel ve malvarlıksal menfaatlerinin korunması için ihtiyaç duyacakları korumanın içeriğinin değişmesidir. Bu şekilde, günlük hayatta mantıklı şekilde hareket etmek suretiyle kendi şahsi ve maddi menfaatlerini koruyamayacak durumda olan kişilerin, başkaları tarafından istismar edilmeleri engellenmek istenmiştir. Hukuk tarafindan iradelerine sonuç bağlanmamış olan kimselerin hukuka aykırı fiillerinden doğacak olan sorumluluk da aynı düşüncelerle farklı esaslara tabi tutulmuştur ${ }^{14}$.

Kanun koyucu tarafından özel bir koruma gereksinimi görülen bazı hallerde, söz konusu şartları taşıyan kimselerin korunması için fiil ehliyetinin sınırlandırılması gerekmez. Korumaya ihtiyacı olmakla birlikte, bu korumanın fiil ehliyetinin sınırlandırılmasını gerektirecek boyutta olmadığı haller bakımından kayyımlık ve yasal danışmanlık kurumları düzenlenmiştir (TMK m 426 vd). Nitekim koruma amacıyla özgürlüğün kısıtlanmasında da kural olarak kişinin fiil ehliyeti sınırlanmamakta, kişi, ihtiyacı olduğu kişisel korumanın sağlanması amacıyla bir kuruma yerleştirilmekte veya orada alıkonulmaktadır.

\footnotetext{
Oğuzman K, Seliçi Ö ve Oktay-Özdemir S, Kişiler Hukuku- Gerçek ve Tüzel kişiler (17. Bası, Filiz 2018) N 138 vd; Mustafa Dural and Tufan Öğüz, Türk Özel Hukuku-Cilt II-Kişiler Hukuku (19. Baskı, Filiz 2018) N 222; Helvacı S, Gerçek Kişiler (8. Bası, Legal 2017) 49.

10 Oğuzman, Seliçi ve Oktay-Özdemir (n 9) N 141; Dural and Öğüz (n 9) N 229 vd; Serozan R, Medeni Hukuk- Genel BölümKişiler Hukuku (8. Bası, Vedat 2018). Helvacı (n 9) 50.

11 Oğuzman, Seliçi ve Oktay-Özdemir (n 9) N 251; Dural and Öğüz (n 9) N 334 vd: Yazarlar "Ehliyetli” kavramını tercih etmektedirler; Serozan (n 10) § 2 N 5; Helvacı (n 9) 64.

12 Oğuzman, Seliçi ve Oktay-Özdemir (n 9) N 253; Dural and Öğüz (n 9) N 352 vd; Serozan (n 10) § 2 N 6; Helvacı (n 9) 67 vd.

13 Oğuzman, Seliçi ve Oktay-Özdemir (n 9) N 289 vd; Dural and Öğüz (n 9) N 431 vd; Serozan (n 10) § 2 N 10; Helvacı (n 9) $77 \mathrm{vd}$.

14 Dural and Öğüz (n 9) N 235.
} 
Buraya kadar aktarmış olduğumuz esaslardan anlaşılacağı üzere, vesayet hukuku, kişi özgürlüklerine, kişinin ihtiyaç duyduğu koruma ile orantılı şekilde müdahale edilmesi prensibi üzerine kurulmuştur. Vesayet hukuku alanında geçerli olan bu esas, orant1l1l1k ilkesi olarak ifade edilir ${ }^{15}$.

Vesayet hukukunun uygulama alanı, kural olarak gerçek kişilerin korunması ile sınırlıdır. Kanun koyucu, istisnai bir düzenleme ile tüzel kişinin gerekli organlardan yoksun kalması ve yönetiminin de başka yoldan sağlanamaması şartlarıyla tüzel kişiye kayyım atanmasını mümkün görmüştür (TMK m 427, b. 4).

Vesayet hukuku alanında 'tip sınırlılığı' ilkesi geçerlidir. Bu şekilde vesayet kurumu kapsamında kişinin korunması için başvurulabilecek olan tedbirler sınırlı sayıda düzenlenmiş olup, kanun tarafından öngörülmüş olanlar haricindeki diğer tedbirlere başvurulması mümkün değildir. Kanun koyucu tarafından öngörülen tedbirlerin kapsamı da emredici şekilde düzenlenmiş olduğundan, bu alanda tipe bağl11ık ilkesinin de geçerli olduğu ifade edilmelidir ${ }^{16}$. Kanun koyucu gerek orant1l11ık ilkesi ile gerekse tipe bağlılık ve tip sinırlılığı ilkeleri ile, kendisine koruma sağlanan kişinin hak ve özgürlüklerinin vesayet kurumunun uygulanması suretiyle ihlal edilmemesini teminat altına almak istemiştir.

Sonuç olarak, koruma amacıyla özgürlüğün korunması bir vesayet tedbiri olması itibariyle, birincil amacı, özgürlüğ̈̈ sınırlanan kişinin kendisinin korunmasıdır ${ }^{17}$. Söz konusu tedbirin uygulanması, tek başına fiil ehliyetini ortadan kaldırmaz. Ancak kişi hürriyetini kısıtlar ${ }^{18}$. Bununla birlikte koruma amacıyla özgürlüğü k1sitlanan tam ehliyetli kişi, şartları varsa ayrıca TMK m 405 vd hükümleri uyarınca kısıtlanabilir ${ }^{19}$. Kişi muhtaç olduğu kişisel korumayı gerçekleştirebilecek bir kuruma yerleştirilerek ya da bu tür bir kurumda alıkonularak, kendi sorumluluğunu tekrar üstlenmesi ve yardıma ihtiyaç duymaksızın insan onuruna yakışır bir yaşam sürdürebilmesi hedeflenir $^{20}$. Yoksa koruma amacıyla özgürlüğün sınırlanması ile özgürlüğü

\footnotetext{
Dural, Öğüz ve Gümüş (n 31) N 1920; Öztan (n 7) 1265.

6 Dural, Öğ̈̈z ve Gümüş (n 31) N 1931 vd; Öztan (n 7) 1266.

17 Spirig (n 3) Art 397a N 196; Geiser T, 'Art 397a-405a' in Heinrich Honsell, Nedim Peter Vogt and Thomas Geiser (eds) Basler Kommentar zum Schweizerischen Privatrecht, Zivilgesetzbuch I (3rd edn, Helbing \& Lichtenhahn 2002) Vor Art 397a-f, N 9; Dural, Öğüz ve Gümüş (n 31) N 2169; Akıntürk ve Ateş (n 1) 506; Selma Hülya İmamoğlu, 'Hukuki Açıdan, Özellikle Koruma Amacıyla Özgürlüğün Kısıtlanmasına İlişkin Hükümler Çerçevesinde Zorla Tedavi’ (2012) VII (3-4) Erciyes Üniversitesi Hukuk Fakültesi Dergisi 29-59 41; Köksal Kocaağa, 'Koruma Amacıyla Özgürlüğün Kısıtlanması', (2006) X (1-2) Gazi Üniversitesi Hukuk Fakültesi Dergisi, 36; Koruma amacıyla özgürlüğün kısıtlanmasının kişinin kendisinin yanı sıra ayrıca tehlike oluşturduğu toplumun korunmasına hizmet ettiği yönünde bkz Kılıçoğlu (n 1) 586.

18 Peter Tuor, Bernhard Schnyder, Jörg Schmid and Alexandra Jungo, Das Schweizerische Zivilgesetzbuch (14th edn, Schulthess 2015) §57 N 1.

19 Spirig (n 3) Art 397a N 17.

20 Dural, Öğüz ve Gümüş (n 31) N 2169; Akıntürk ve Ateş (n 1) 506; Pelin Çavuşoğlu Işıntan, 'Türk Hukukunda Yeni Bir Müessese: Koruma Amacıyla Kişi Özgürlüğunün Kısıtlanması (TMK m 432-437)’, (2002) I (2) Galatasaray Üniversitesi Hukuk Fakültesi Dergisi 298; Aksi yönde Dağlı (n 2) 39.
} 
sınırlanan kişilerin cezalandırılması amaçlanmamaktadır ${ }^{21}$. Koruma amacıyla özgürlüğün sınırlandırılmasının şartlarını düzenleyen TMK m 432 hükmünün de bu amaç kapsamında incelenmesi ve bu amaca ulaşmaya ne denli elverişli olduğunun gözden geçirilmesi gerekir.

\section{Koruma Amacıyla Özgürlüğün Kısıtlanmasına Dair Hükümlerin Uygulama Alanına Giren Kişiler}

Koruma amacıyla özgürlügün kısıtlanması, gerçek kişilere yönelik bir vesayet tedbiridir. Kanun koyucu, TMK m 432 hükmünün uygulama alanını "ergin kişiler” ifadesi ile belirlemiştir. Bu halde, koruma amaciyla özgürlüğü sınırlanan kişinin k1sıtlı olup olmamasının bir önemi yoktur ${ }^{22}$. İlgili TMK m 432 hükmü, özgürlüğü kısıtlanacak olan kişinin ergin olmasından söz etmiştir. Bu sebeple, TMK m 432 vd hükümleri, kısıtlanarak velayet altına koyulmuş olan erginler bakımından da uygulama alanı bulur ${ }^{23}$.

Kısıtlı bir kişinin koruma amacıyla özgürlüğünün sınırlandırılmasına dair bir takım esaslar, TMK m 447 hükmünde ayrıca düzenlenmiştir. Buna göre gecikmesinde sakınca bulunan hâllerde vasi, koruma amacıyla özgürlüğün kısıtlanmasına ilişkin hükümlere göre kısıtlıyı bir kuruma yerleştirebilecek veya orada alıkoyabilecektir. Vasi, bu yola başvurmuş olması halinde durumu derhal vesayet makamına bildirmekle yükümlü tutulmuştur. Kanun koyucu, TMK m 462, b. 13 hükmünde ise vesayet

21 Kişi özgürlüğünün kişinin kendisinin korunması dışında başka bir amaçla kısıtlanamayacağı yönünde Mustafa Alper Gümüş, 'Kısıtlı veya Kısıtlı Olmayan Ergin Kişilerin Koruma Amaçlı Özgürlüğünün Kısıtlanması (TMK 432-437)', (2004) I (2) Yeditepe Üniversitesi Hukuk Fakültesi Dergisi 193; Koruma tedbirlerinde toplumsal düzeninin sağlanması hedeflenmekle birlikte, bu halde korumanın aynı zamanda kişinin kendisine karşı olduğu yönünde Dağlı (n 2) 9.

22 Öztan (n 7) 1354; Akıntürk ve Ateş (n 1) 506; Gümüş (n 21) 194; Dağlı (n 2) 14; Kaynak İsviçre Medeni Kanunu mülga m 397a hükmünde, koruma amacıyla özgürlüğün kısıtlanmasının tam ehliyetliler ve kısıtlılar bakımından uygulama alanı bulacağı açıkça ifade edilmişti. 19 Aralık 2008 tarihli Kanun ile mülga m 397a hükmünün yerini almış olan m 426 hükmünde ise bu hususta açık bir ifade yer almamaktadır. Söz konusu değişikliklerle İsviçre Hukuku'nda vesayet sistemi önemli değişikliklere uğramıştır. Bu hali ile İMK. m 426 hükmünün uygulama alnına giren kişiler bakımından yapılması gereken ayrım, özgürlüğü kısıtlanacak kişinin ayırt etme gücüne sahip olup olmadığıdır. Ayırt etme gücüne sahip erginler bakımından İMK. m 426 vd hükümlerinin uygulanması, ilgili kişinin kuruma yerleştirilmesine veya kurumda alıkonulmasına rıza göstermemesi halinde söz konusu olacaktır. Buna karşılık ayırt etme gücü olmayan kimsenin kişisel koruma sağlanması amacıyla bir psikiyatri kurumuna yerleștirilmesi veya orada alıkonulması halinde, rızası olsun ya da olmasın IMK. m 380 hükmünün atfı dolayısıyla İMK. m 426 vd hükümleri uygulama alanı bulacaktır. Ancak ayırt etme gücü olmayan bir kimsenin bedensel bir rahatsızlık dolayısıyla bir hastaneye yerleștirilmesinin gerektiği hallerde İMK. m 378 hükmü gereği, koruma amacıyla yerleştirme kurumuna ilişkin hükümler uygulanmayacaktır. Ayırt etme gücüne sahip olmayan kişinin, örneğin ağır bir zihinsel engel dolayısıyla eğitim için bir kuruma yerleştirilmesi halinde de şayet söz konusu kişi bu tür bir yerleştirmeye mukavemet göstermiyorsa koruma amaciyla yerleştirme kurumuna başvurulması gerekmeyecektir. Tüm bu hallerde ayırt etme gücü olmayan kişinin kendisini temsile yetkili kişi tarafından tıbbi işlemlerde temsili söz konusu olup, bu aşamada çıkan uyuşmazlıklar yetişkinlerin korunması ile görevli olan makam tarafından çözüme kavuşturulacaktır. Yetişkinlerin korunması ile görevli olan makamın kararlarına karşı ise IMK. m 450 hükmü uyarınca yetkili mahkemeye başvurulabilecektir. Bkz 19 Aralık 2008 tarihli Kanun Gerekçesi, BBI 2006 7063, (https://www.admin.ch/opc/de/federal-gazette/2006/7001.pdf Erişim Tarihi 25 Mayıs 2020); Ayırt etme gücü bulunmayan yetişkinlere yapılacak tıbbi müdahalelere onay verilmesi hususunda İsviçre Medeni Kanunu'nda 19 Aralık 2008 tarihli Kanunla yapılan değişiklikler için bkz Saibe Oktay-Özdemir, 'Ayırt Etme Gücü Bulunmayan Yetişkinlere Yapılacak Tıbbi Müdahalelere Onay Konusunda İsviçre Hukukunda Yapılan Değişiklikler', (2016) XI (145-146) Bahçeşehir Üniversitesi Hukuk Fakültesi Dergisi 235 vd.

23 TMK m 447 hükmünün kaynağını teşkil eden IMK. m 406 hükmü, 19 Aralık 2008 tarihli "Yetişkinlerin Korunması, Kişilik Hakkı ve Çocuk Hukuku” başlıklı Kanun ile yürürlükten kaldırılmıştır. Bu kapsamda koruma amacıyla özgürlüğün kısıtlanması bakımından İsviçre Medeni Kanunu ayırt etme gücü olanlar ve olmayanlar arasında bir ayrım yapmak suretiyle düzenleme getirmiştir. Bu konuda açıklayıcı bir şema için bkz Tuor, Schnyder, Schmid and Jungo (n 18) § 57 N 9. 
altındaki kişinin bir eğitim, bakım veya sağlık kurumuna yerleştirilmesini vesayet makamının iznine tabi tutmuştur. Bu halde TMK m 447 hükmü, TMK m 462, b. 13 hükmü ile birlikte yorumlandığında, küçüğün özgürlüğünün korunması amacıyla kısıtlanması hususundaki son kararı vesayet makamının vereceği anlaşılmaktadır. $\mathrm{Bu}$ husus öğretide tartışmalı olup, bu kapsamda ileri sürülen görüşlere TMK m 446 hükmü ile bağlantılı şekilde değinilecektir.

Türk Medeni Kanunu m 446 hükmü uyarınca, vesayet altında olan küçüğün koruma amaciyla bir kuruma yerleştirilmesine veya zaten böyle bir kurumda ise orada alıkonulmasına, vasinin başvurusu üzerine vesayet makamı karar verecektir. Bununla birlikte vasi, gecikmesinde sakınca bulunan hallerde küçüğü bir kuruma yerleştirebilecektir. Ancak bu halde vasinin durumu derhal vesayet makamına bildirmesi öngörülmüştür. Bunun dışında vesayet altındaki küçüğün özgürlüğünün koruma amacıyla kısıtlanmasının bütünüyle TMK m 432 vd hükümlerine tabi olacağ ifade edilmiştir. Kanun koyucu, TMK m 446/III hükmünde, on altı yaşını doldurmamış küçüklerin bu konuda bizzat mahkemeye başvuramayacaklarını ifade etmiştir ${ }^{24}$.

Türk Medeni Kanunu m 445 hükmü, vasinin vesayet altındaki küçüğün bakımı ve eğitimi için gerekli önlemleri almakla yükümlü olduğunu öngörmektedir. Vasi, söz konusu önlemlerin alınması bakımından, vesayet dairelerinin yetkilerine ilişkin hükümler saklı kalmak kaydıyla ana ve babanın yetkilerine sahiptir. Vasinin küçüye karşı özen gösterme yükümlülüğünün kapsamı, küçüğün yararı dikkate alınarak tayin edilir²5. Vasi, küçüğün ihtiyaç duyduğu kişisel korumanın sağlanması ile görevlidir. Küçüğün koruma amacıyla özgürlüğünün kısıtlanması, ancak küçüğün korunmasının başka şekilde sağlanamaması şartıyla söz konusu olabilir ${ }^{26}$. Bu hali ile vasinin özen yükümlülüğü ile vesayet altındaki küçüğün özgürlüğünün koruma amaciyla kısıtlanması arasında sıkı bir bağ bulunmaktadır ${ }^{27}$.

Kanun koyucu, TMK m 462, b. 13 hükmünde ise vesayet altındaki kişinin bir eğitim, bakım veya sağlı kurumuna yerleştirilmesini vesayet makamının iznine tabi tutmuştur. Öğretide TMK m 462, b. 13 hükmünün, bu hususta “örtülü” kanun boşluğu olması dolayısıyla uygulanamayacağı ifade edilmektedir ${ }^{28}$. Bu görüşün en önemli

\footnotetext{
Söz konusu düzenleme 4721 sayılı Türk Medeni Kanunu'nun hazırlandığı sırada yürürlükte olan mülga İMK. m 405a hükmü göz önünde bulundurularak düzenlenmiştir. Ancak, İsviçre Medeni Kanunu m 405a hükmü, 19 Aralık 2008 tarihli Kanun ile yürürlükten kaldırılmıştır. İsviçre kanun koyucusu, küçüğün koruma amacıyla kapalı bir kuruma yerleştirilmesi hususunda velayet ya da vesayet altında olup olmadığına bakmaksızın, koruma amacıyla yerleştirmeye ilişkin İMK. m 426 vd hükümlerinin kıyasen uygulanmasını düzenlemiştir (velayet altındaki küçükler bakımından İMK. m 314b; vesayet altındaki küçükler bakımından İMK. m 327c). Bu kapsamda vasi, acil hallerde dahi küçüğü, koruma amacıyla bir kuruma yerleştirme hususunda yetkiye sahip değildir. Bunun yanı sıra kanun koyucu, çocukların yetkili makama başvurması için öngörülmüş olan 16 yaş sınırını kaldırmış ve ayırt etme gücüne sahip olmasını yeterli görmüştür (İMK. m 314b). Bkz Tuor, Schnyder, Schmid and Jungo (n 18) § 44 N 61.

25 Selma Hülya İmamoğlu, 'Vesayet Altındaki Küçüğün Koruma Amacıyla Özgürlüğünün Kısıtlanması (TMK 446)', (2005) LIV (4) Ankara Üniversitesi Hukuk Fakültesi Dergisi 299-342 ('Vesayet Altındaki Küçüğün Korunması') 305.

26 İbid (n 25) 308.

27 İbid (n 25) 308.

28 Gümüş (n 21) 192; Kocaağa (n 17) 44 dpn 35; İmamoğlu 'Vesayet Altındaki Küçüğün Korunması' (n 25) 320 vd.
} 
sebebi, kaynak İsviçre Medeni Kanunu'nun TMK m 446 hükmüne tekabül eden mülga m 405a hükmünün getirilmiş olduğu 1978 revizyonunda, TMK m 462, b. 13 hükmünü karşılayan İMK. m 421, b. 13 hükmünün yürürlükten kaldırılmış olmasıdır² ${ }^{29}$.

Kanaatimizce TMK m 446 hükmü. 462, b. 13 hükmü ile çelişmemekte, aksine söz konusu hükmü tamamlamaktadır. Vasi, TMK m 446 uyarınca, gecikmesinde sakınca bulunan hallerde küçüğün koruma amacıyla bir kuruma yerleştirilmesi bakımından yetkili kılınmış olmakla birlikte, en nihayetinde bu durumu gecikmeksizin vesayet makamına bildirmekle yükümlüdür. O halde söz konusu m 446 hükmü, m 462, b 13 hükmü ile birlikte yorumlandığında, vesayet makamının küçüğün kuruma yerleştirilmesi veya orada alıkonulmasına dair uygulamayı onaylamaması halinde, küçüğün kurumdan çıkarılmasının gerekeceği anlaşılmaktadır. Aynı husus, vesayet altındaki erginlerin TMK m 447 uyarınca vasi tarafından özgürlüğü kısıtlanarak bir kuruma yerleştirilmesi veya orada alıkonulması halinde de söz konusudur. Koruma amacıyla özgürlüğün kısıtlanması kişilik hakkına önemli derecede etki eden bir kısıtlama olup, bu yönde bir kararın mahkeme tarafından verilmiş olması, kişilik hakkının etkin şekilde korunmasına hizmet eder. Nitekim İsviçre Medeni Kanunu'nda 19 Aralık 2008 tarihli Kanun ile yapılan değişiklik sonucunda, vasiye tanınmış olan bu yetki tamamen kaldırılarak, vesayet altındaki kimselerin koruma amacıyla yerleştirilmesi bakımından yetişkinleri koruma makamı ${ }^{30}$ ile çocukları koruma makamı (IMK. m 314b) yetkili kılınmıştır.

Bunun dışında vesayet altındaki kişinin bir kuruma yerleştirilmesi için mutlaka koruma amacıyla özgürlügünün kısıtlanması gerekmez. Dolayısıyla vesayet altındaki kişinin kendi iradesi ile bir kuruma yerleştirilmesi halinde de TMK m 462, b. 13 hükmüne başvurmak gerekecektir. Nitekim vesayet altındaki kişinin yerlelşim yerinin değiştirilmesi de TMK m 462, b. 14 uyarınca vesayet makamının denetimine tabidir. Kısıtlıların bir kuruma yerleştirilmesi, çoğunlukla yerleşim yerinin değiştirilmesine de yol açacaktır.

Kanun koyucunun TMK m 432 hükmünde ergin kişilerden söz etmiş olması dolayısıyla, TMK m 446 hükmü olmasaydı, koruma amacıyla kişi özgürlüğünün kısıtlanmasının küçükler bakımından uygulama alanı bulmayacağı sonucuna varmak gerekecekti. Ancak TMK m 446 hükmü dolayısıyla bu hususta tereddüt etmemek gerekir. Bununla birlikte vesayet altındaki küçük bakımından koruma amacıyla özgürlüğün kısıtlanmasına cevaz veren kanun koyucu, velayet altındaki küçükler bakımından bu yönde bir düzenlemeye gitmediğinden, TMK m 432 vd hükümlerinin velayet altındaki küçükler bakımından uygulanması mümkün görünmemektedir. $\mathrm{Bu}$ husus, öğretide kanun boşluğu olarak nitelendirilmekte ve bu boşluğun velayet altındaki küçügün koruma amacıyla özgürlüğünün kısıtlanmasına dair esasları

\footnotetext{
29 İbid (n 25) 321.

30 Ayrıca bkz yukarıda 22 numaralı dipnot.
} 
düzenleyen İMK m 314a hükmüne uygun bir şekilde doldurulması savunulmaktadır ${ }^{31}$. Söz konusu İMK. m 314a hükmü, 19 Aralık 2008 tarihli Kanun ile yürürlükten kaldırılmıştır. Küçüklerin koruma amacıyla özgürlüklerinin sınırlandırılması, 1 Ocak 2013 tarihinde yürürlüğe girmiş olan m 314b hükmü ile düzenlenmektedir. Buna göre, küçügün korunması için bir kuruma veya psikiyatri kliniğine yerleştirilmesinin gerekli olduğu hallerde, koruma amacıyla özgürlüğün kısıtlanmasına ilişkin hükümler kıyasen burada da uygulanacaktır. Ancak söz konusu m 314b hükmündeki atıf, koruma amacıyla özgürlüğün kısıtlanmasına dair usule ilişkin olup, küçüğün koruma amacıyla özgürlüğünün kısıtlanması bakımından hâkimin vereceği kararın İMK. m 310 hükmü esaslarına tabi olduğu kabul edilmektedir ${ }^{32}$.

4721 sayılı Türk Medeni Kanunu Gerekçesi’nde velayet altındaki küçükler bakımından koruma amacıyla özgürlüğün kısıtlanmasına yer verilmemiş olması esasen açıklanmıştır. Buna göre: "Madde sadece ergin kişilerin bir kuruma yerleştirilmesini veya kurumda alıkonulmasını öngörmektedir. Ergin olmayan kişiler, yani küçükler bu maddenin kapsamına girmemektedir. Bu kişilere ilişkin koruma önlemleri daha önceki maddelerde hükme bağlanmıştır",33. Koruma amacıyla özgürlüğün kısıtlanmasına dair TMK m 432 vd hükümleri söz konusu Gerekçe kapsamında yorumlandığında, kanun koyucunun velayet altındaki küçüğün korunmasına bilinçli olarak TMK m 432 vd hükümlerinde yer vermemiş olduğu anlaşılmaktadır. Velayet altındaki küçüklerin korunmasının TMK m 346 vd hükümleri kapsamında sağlanması arzu edilmiştir.

Küçüklerin koruma amacıyla özgürlüklerinin sınırlandırılması bakımından TMK m 346 vd hükümlerine göre bir değerlendirme yapılması, kanaatimizce de amaca uygundur. Zira küçüklerin korunması, ergin kişilerin korunmasından farklı esaslara tabidir. Küçüklerin korunması aşamasında küçügün üstün yararının daima gözetilmesi gereği, bedensel, zihinsel ve ahlaki gelişimini tehlikeye atabilecek unsurların ivedilikle bertaraf edilmesi gerekmektedir ${ }^{34}$. Nitekim 19 Aralık 2008 tarihli Kanun ile değiştirilen İsviçre Medeni Kanunu da bu yönde bir çözüm benimsemiştir. İsviçre kanun koyucusu, küçüğün koruma amacıyla kapalı bir kuruma yerleştirilmesi hususunda velayet ya da vesayet altında olup olmadığına bakmaksızın, koruma amacıyla yerleştirmeye ilişkin İMK. m 426 vd hükümlerinin kıyasen uygulanmasını düzenlenmiştir (velayet altındaki küçükler bakımından İMK. m 314b; vesayet altındaki küçükler bakımından İMK. m 327c). İsviçre Medeni Kanunu, vesayet altındaki çocuğun hukuki durumunun velayet altındaki

\footnotetext{
31 Mustafa Dural, Tufan Ögüz ve Alper Gümüş, Türk Özel Hukuku-Cilt III-Aile Hukuku (Filiz 2019) N 2168; Akıntürk ve Ateş (n 1) 506; Gümüş (n 21) 192.

32 Tuor, Schnyder, Schmid and Jungo (n 18) § 57 N 8.

33 Türk Medeni Kanunu Tasarısı ile Türk Kanunu Medenisinde Değişiklik Yapılması Hakkında Kanun Tasarısı ve Ankara Milletvekili Yücel Seçkiner'in; Ankara Milletvekili Esvet Özdoğu ve Dört Arkadaşının; Aynı Kanunda Değişiklik Yapılmas Hakkında Kanun Teklifleri ve Adalet Komisyonu Raporu (1/611, 1/425, 2/361, 2/680)", https://www.tbmmgov.tr/sirasayi/ donem21/yil01/ss723mhtm Erişim Tarihi 9 Mayıs 2020.

34 Elçin Grassinger G, Küçüğün Kişi Varlı̆̆ının Korunması İçin Alınacak Tedbirler (On İki Levha 2009) 67, 81, 100 vd.
} 
çocukla aynı olacağını öngörmüştür (IMMK. m 327b). Koruma amacıyla yerleştirme kurumuna yapılmış olan atıf, yalnızca prosedüre ilişkin olup, kuruma yerleştirmenin esasları bakımından çocuk hukukuna hakim prensiplerin gözetileceği hükme bağlanmıştır. Buna göre küçük ister velayet altında ister vesayet altında olsun, koruma amacıyla bir kuruma yerleştirilmesi için küçüğün İMK. m 426 hükmünde öngörülmüş olan zayıflık hallerinden biri sebebiyle koruma ihtiyacı içerisinde olması şartı aranmayacaktır. Küçüğün koruma amacıyla bir kuruma yerleştirilmesi bakımından önemli olan, çocuğun, yaşadığı çevrede geçerli olan şartlar dolayısıyla bedensel, zihinsel ya da ahlaki bakımdan gelişiminin tehlikede olması ve kapalı bir kuruma yerleştirilmesinin koruma amacıyla ölçülü olmasıdır ${ }^{35}$.

Kanaatimizce çocukların korunması bakımından velayet altındaki çocuk ile vesayet altındaki çocuk arasında bir ayrım yapmayan ve çocukların korunması hususundaki genel ilkelerin göz önünde bulundurulmasına imkân tanıyan İsviçre Mednei Kanunu'ndaki ilgili düzenlemeler, çocuğun etkin bir şekilde korunmasına hizmet etmektedir. Temennimiz, kanun koyucunun Türk Medeni Kanunu'nun velayet altında olan çocuklar ile vesayet altında olan çocuklar arasında ayrım yapmadan, tarafı olduğumuz Çocuk Haklarının Korunmasına İlişkin Avrupa Sözlşemesi'nde de ifadesini bulan genel ilkelerin, koruma amacıyla özgürlüğün kısıtlanması alanında da uygulama alanı bulmasını teminat altına alan düzenlemelere yer vermesidir.

\section{Koruma Amacıyla Özgürlüğün Kısıtlanmasının Şartları}

\section{Genel Olarak}

Kanun koyucu koruma amacıyla özgürlüğün kısıtlanmasının şartlarını TMK m 432 hükmünde düzenlemiştir. Düzenlemenin ilk fikrasına göre; "Akll

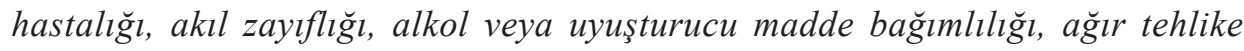
arzeden bulaşıcı hastalık veya serserilik sebeplerinden biriyle toplum için tehlike oluşturan her ergin kişi, kişisel korunmasının başka şekilde sağlanamaması hâlinde, tedavisi, eğitimi veya ıslahı için elverişli bir kuruma yerleştirilir veya alıkonulabilir. Görevlerini yaparlarken bu sebeplerden birinin varlığını öğrenen kamu görevlileri, bu durumu hemen yetkili vesayet makamına bildirmek zorundadırlar". Hükmün ikinci fıkrası ile, koruma amacıyla özgürlüğün kısıtlanmasında kişinin çevresine getirdiği külfetin de dikkate alınacă̆ 1 ifade edilmiştir. Hükmün son fıkrasında ise özgürlüğü kısıtlanan kişinin durumu elverince derhal kurumdan çıkarılması emredilmiştir.

Kişinin kendi isteği ile tedavisi, bakımı veya eğitimi için bir kuruma yerleşmesi durumunda, koruma amacıyla özgürlüğün kısıtlanmasından söz edilemez. Geçerli bir 
irade, öncelikle kişinin ayırt etme gücünün bulunmasını gerektirir. Koruma amacıyla özgürlüğün kısıtlanmasından söz edebilmek için, kişinin bu kuruma iradesi hilafına yerleştirilmesi veya kurumda iradesi hilafına alıkonulması gerekir ${ }^{36}$. Bu halde kendi isteği ile kuruma yerleşen bir kişi, kural olarak istediği zaman kurumu terk edebilir. Ancak böyle bir kişinin kurumda kalmasının zorunlu olduğu düşünülüyorsa kişi, TMK m 432 vd hükümlerinin şartları varsa özgürlüğün hâkim kararı ile kısıtlanması ile kurumda kalmaya zorlanabilir ${ }^{37}$.

İsviçre Medeni Kanunu m 427 hükmü, kuruma psikolojik rahatsızlık dolayısıyla kendi isteği ile yerleşmiş olan kişilerin kurumdan çıkmak istemeleri halinde, bir takım şartlarla kurum yönetimi tarafından üç gün boyunca alıkonulabileceğini öngörmüştür. Bunun için psikolojik rahatsızlığı olan kişinin kurumdan çıkması halinde kendi yaşamı veya vücut bütünlüğünün ya da bir üçüncü kişinin yaşamı veya vücut bütünlügüünün tehlike altında olması aranmıştır ${ }^{38}$. İlgili kişinin zorla alıkonulduğu üç günlük sürede, koruma amacıyla özgürlüğün korunmasına dair bir karar alınmamış olması durumunda, kişi, söz konusu kurumdan çıkabilecektir. Söz konusu kişinin kurumda alıkonulması halinde, kendisine, yazılı şekilde koruma amacıyla özgürlüğün kısıtlanmasına karşı itiraz edebileceği hususunda bilgi verilecektir.

\section{Kişinin Kanun'da Sayılan Zayıflık Hallerinden Biri Sebebiyle Kişisel Korumaya İhtiyaç Duyması}

Bir kişinin özgürlüğünün koruma amaciyla kısıtlanabilmesi, TMK m 432/I hükmünde sayılan sebeplerden biri dolayısıyla kişisel korumaya gereksinim ${ }^{39}$ duymasına bağlıdır. Kanun hükmünde sayılan sebepler; akıl hastalığı, akıl zayıflığ1, alkol veya uyuşturucu madde bağımlılığ 1 , ağır tehlike arz eden bulaşıcı hastalık ${ }^{40}$ veya serserilik ${ }^{41}$ halleri olup, söz konusu sebepler sınırlı sayıdadır ${ }^{42}$.

İsviçre Medeni Kanunu, mülga m 397a hükmü gibi, şu anda yürürlükte bulunan İMK. m 426 hükmü de, serserilik ve ağır tehlike arz eden bulaşıcı hastalık hallerini

$\overline{36}$ Tuor, Schnyder, Schmid and Jungo (n 18) § $57 \mathrm{~N} 2$.

37 İbid (n 18) § 57 N 21.

38 Ayrıca bkz Tuor, Schnyder, Schmid and Jungo (n 18) § $57 \mathrm{~N} 21 \mathrm{vd}$.

39 Geiser (n 17) Art 397a N 3-5; Bu şartlarla hangi ergin kişilerin toplum için tehlike oluşturacağının düzenlendiği yönünde Kılıçoğlu (n 1) 593.

40 Kanun koyucu TMK m 436/I, b. 5 hükmünde akıl hastalığı, akıl zayıflığı, alkol veya uyușturucu madde bağımlılığı, ağır tehlike arz eden bulaşıcı hastalığı olanlar hakkında özgürlüğün kısıtlanması kararı verilebilmesi için resmi sağlık kurulu raporu aramıştır.

41 Barınma yeri olmayan, kötü sağlık koşulları içinde yaşayan, giyim ve beslenme gibi günlük ihtiyaçlarını karşılayamayan ya da sosyal statüsü veya ekonomik koşulları ile bağdaşmayacak şekilde yaşam sürenlerin bu şartları sağladığı ifade edilmektedir. Kılıçoğlu (n 1) 588. Anayasa m 19/II hükmü gerekçesi uyarınca; “(...) 'Serseri' terimi, 'Muntazam ve normal geçim kaynağından mahrum ve meskeni bulunmayan' kimseleri ifade eder”. Bkz Madde Gerekçeli Türkiye Cumhuriyeti Anayasas1, TBMM, $2008<$ https://acikerisimtbmmgov.tr/xmlui/bitstream/handle/11543/1169/200901027. pdf? sequence=1\&isAllowed=y $>$ Erişim Tarihi 12 Mayıs 2020.

42 Spirig (n 3) Art 397a N 2; Geiser (n 17) Art 397a N 6; Oliver Guillod, 'Art 426-439'in Andrea Büchler, Christoph Häfeli, Audrey Lauba, Martin Stettler (eds) FammKomm: Erwachsenenschutz (Stämpfli 2013) Art 426 N 34; Dural, Ögüz ve Gümüş (n 31) N 2173; Öztan (n 7) 1355; İmamoğlu 'Zorla Tedavi' (n 17) 41. 
koruma amacıyla özgürlüğün korunması sebepleri arasında saymamıştır. Mülga m 397a hükmünde sayılan zayıflık halleri, akıl hastalığ1, akıl zayıflığ1, alkol ve diğer bağımlılık halleri ile ağır bakımsızlık haliydi. İsviçre Medeni Kanunu m 426 hükmü ise yalnızca üç tür zayıflık hali saymaktadır. Bunlar; psikolojik rahatsızlık, zihinsel engel ve ağır bakımsızlık halidir. Kanun koyucu, 19 Aralık 2008 tarihli Kanun’un gerekçesinde psikolojik rahatsızlığın bağımlılık hallerini de kapsadığını açıkça ifade etmiştir $^{43}$. Görüldüğü üzere, mülga İMK. m 397a hükmü gibi, yürürlükte olan m 426 hükmü de, koruma amacıyla özgürlüğün kısıtlanması sebebi olarak "ağır bakımsızlık" haline yer vermiştir. Bu hali ile ağır bir şekilde bakımsız kalmış olan kimse, bu bakımsızlık hangi sebepten kaynaklanırsa kaynaklansın, şayet yardım görmemesi halinde içinde bulunacağı şartlarda yaşaması insanlık onuru ile bağdaşmayacaksa koruma amaciyla bir kuruma yerleştirilebilecek veya orada alıkonabilecektir ${ }^{44}$. Kişinin ağır nitelikte bakımsız kalmış olması, özgürlüğün kısıtlanması için tek başına yeterli görülmemektedir. Burada ayrıca, kişiye koruma sağlanmaması halinde ciddi şekilde zarar görme tehlikesinin varlığg aranmaktadır $^{45}$.

Koruma amacıyla özgürlüğün kısıtlanmasında AY m 19 hükmü ile koruma altına alınan kişi hürriyetinin sınırlandırılması söz konusudur. Anayasa ile güvence altına alınan bu hakkın sınırlandırılması bakımından yasallık şartı arandığından, TMK m 432 hükmünde açıcça sayılmamış bir sebep dolayısıyla kişi özgürlüğünün sınırlandırılması mümkün değildir ${ }^{46}$. Bu sebeple ağır bakımsızlık halinin Türk Hukuku'nda özgürlüğün kısıtlanmasına dayanak oluşturması mümkün görünmemektedir.

Kanun koyucu, TMK m 436, b. 5 hükmünde, akıl hastalığı, akıl zayıflığı, alkol veya uyuşturucu madde bağımlılığı, ağır tehlike arz eden bulaşıcı hastalığı olanlar hakkında özgürlüğün kısıtlanması kararı verilebilmesi için resmi sağlık kurulu raporu aramıştır. Serserilik ise her türlü delille ispatlanabilir ${ }^{47}$.

Ağır tehlike arz eden hastalıklar bakımından kanun koyucu, örnek mukabilinden dahi olsa belirli hastalıkları sayma yoluna gitmemiştir. Türk Medeni Kanunu'nun gerekçesi uyarınca; "Ağır tehlike arzeden hastalıkların neler olduğunun belirlenmesi tıp biliminin işi olmakla beraber, buraya AIDS, ilerlemiş verem, kolera ve veba gibi

\footnotetext{
43 Bkz BBI 2006 7062, (https://www.admin.ch/opc/de/federal-gazette/2006/7001.pdf Erişim Tarihi 2 Mayıs 2020); Ayrıca bkz Tuor, Schnyder, Schmid and Jungo (n 18) § 57 N 12 vd, özellikle 13; Guillod (n 42) Art 426 N 34 vd.

44 Bkz BBI 2006 7062, (https://www.admin.ch/opc/de/federal-gazette/2006/7001.pdf Erişim Tarihi 2 Mayıs 2020); Ayrıca bkz Tuor, Schnyder, Schmid and Jungo (n 18) § 57 N 15; Guillod (n 42) Art 426 N 40, 41; Ağır bakımsızlık halinin AïHS m 5 hükmünde yer alan serserilik halinden daha dar bir gruba işaret etmesi dolayısıyla söz konusu hükmün AİHS m 5 hükmüne aykırı olmadığı yönünde Spirig (n 3) Art 397a N 94; Geiser (n 17) Art 397a, N 10; Ağır bakımsızlık hali ile serserilik halinin bütünüyle farklı şartlar olduğu yönünde Guillod (n 42) Art 426 N 45: Yazar ayrıca ağır bakımsızlık halinin AİHS m 5/I hükmünün e bendinde sayılmamış olması dolayısıyla kişi özgürlüğünün ihlali olarak değerlendirilebileceği görüşündedir (N 44).

45 Tuor, Schnyder, Schmid and Jungo (n 18) § 57 N 12 15; Ayrıca bkz BGer 5A_189/2013, 3 numaralı gerekçe, (www.bger.ch Erişim Tarihi 22 Mayıs 2020)

46 Çavuşoğlu Işıntan (n 20) 298; Kocaağa (n 17) 36; Aksi yönde Gümüş (n 21) 202: Yazar ağır bir kanser hastasının TMK m 432 hükmü kapsamında korunabileceği görüşünü savunduğundan, hükümde sayılan sebeplerin sınırlı sayı ilkesine tabi olmadığı görüşünde olduğu ifade edilebilir.

$47 \quad$ Kilıçoğlu (n 1) 588.
} 
bulaşıcı hastalıkların gireceği düşünülebilir"'48. Görüldüğü üzere, kanun koyucu, hangi hastalıkların ağır tehlike arz eden bulaşıcı hastalık olduğu hususundaki değerlendirmeyi tıp bilimine bırakmak suretiyle, hükmün güncel nitelikte bulaşıcı hastalıklar karşısında da uygulanmasını arzu etmiştir. Bununla birlikte, AIDS hastalığının gerekçede örnek mukabilinden sayılmış olması eleştirilmiştir. Bunun sebebi, AIDS hastalığının aynı ortamda bulunmakla başkalarına geçebilen bir hastalık olmamas1, yani epidemik olarak nitelendirilememesidir ${ }^{49}$.

\section{Kişinin ihtiyaç duyduğu kişisel korumanın ancak özgürlüğ̈̈n stnırlandırılmast suretiyle sağlanabilmesi}

Vesayet hukukuna hâkim olan ölçülülük ilkesi burada da geçerlidir ${ }^{50}$. Kanun koyucu, TMK m 432 hükmü ile, özgürlügün kısıtlanması için kişinin bu sebeplerden biri sebebiyle kişisel korumaya ihtiyaç duymasının yanı sıra, söz konusu korumanın başka şekilde sağlanamayacak olması gerektiğini de açıkça ifade etmiştir. Bir diğer ifadeyle, somut olay kapsamında kişinin korunması için özgürlügünün kısıtlanması zorunlu ve kaçınılmaz olmalıdır ${ }^{51}$. Vesayet hukuku, kişi özgürlükleri üzerinde önemli nitelikte sınırlayıcı bir etkiye sahiptir ${ }^{52}$. Ancak bu sinıllandırma, özgürlüklerine etki edilen kişinin kendisinin korunmasına hizmet eder. Dolayısıyla vesayet hukuku kapsamında alınacak olan bir tedbir, kişinin korunma gereksinimiyle orantılı olmalıdır. Korunma ihtiyacının kişi özgürlüklerine daha az müdahale eden bir tedbirle sağlanması mümkün ise koruma amacıyla özgürlügün sınırlandırılmasına başvurulmaz ${ }^{53}$. Örneğin bir kimseye sosyal yardım bağlanması korunması için yeterli olacaksa ve bu yönde bir yardımın sağlanması mümkünse özgürlüğü kısıtlanamaz ${ }^{54}$.

Kişi özgürlüğünün kısıtlanması, ancak kişinin ihtiyacı olan korumayı sağlamaya elverişli olması halinde başvurulan bir tedbir olmalıdır ${ }^{55}$. Bu kurum ile evvela, kişinin kendi sorumluluklarını bizzat yerine getirebilme ve yardıma ihtiyaç duymaksızın yaşayabilme kabiliyetine kavuşması hedeflenir. Ancak bunun mümkün olmadığı hallerde, özgürlüğün kısıtlanması bu defa kişinin insan onuruna yakışır bir yaşam

48 Türk Medeni Kanunu Tasarısı ile Türk Kanunu Medenisinde Değişiklik Yapılması Hakkında Kanun Tasarısı ve Ankara Milletvekili Yücel Seçkiner'in; Ankara Milletvekili Esvet Özdoğu ve Dört Arkadaşının; Aynı Kanunda Değișiklik Yapılması Hakkında Kanun Teklifleri ve Adalet Komisyonu Raporu (1/611, 1/425, 2/361, 2/680)”, https://www.tbmmgov.tr/sirasayi/ donem21/yil01/ss723mhtm Erişim Tarihi 9 Mayıs 2020.

49 Çavuşoğlu Işıntan (n 20) 301; Kocaağa (n 17) 41.

50 Spirig (n 3) Art 397a N 257 vd; Geiser (n 17) Art 397a N 2, 12 vd; Dural, Öğüz ve Gümüş (n 31) N 2180; İmamoğlu 'Zorla Tedavi' (n 17) 42; Koruma amacıyla özgürlüğün kısıtlanması tedbirine, ancak uygulanmasının zorunlu ve kaçınılmaz olduğu hallerde başvurulabileceği yönünde Akıntürk ve Ateş (n 1) 508.

51 Tuor, Schnyder, Schmid and Jungo (n 18) § 57 N 16; Öztan (n 7) 1357; Akıntürk ve Ateş (n 1) 508.

52 Dural, Öğüz ve Gümüș (n 31) N 2180; Öztan (n 7) 1357.

53 Geiser (n 17) Art 397a N 12; Tuor, Schnyder, Schmid and Jungo (n 18) § 57 N 16; Akıntürk ve Ateş (n 1) 508; Gümüș (n 21) 203 vd; Bu konuda örnekler için bkz Kıliçoğlu (n 1) 589;

54 Spirig (n 3) Art 397a N 298; Geiser (n 17) Art 397a N 13; Ayrıca bkz Yarg. 18. HD., 14.6.2016 T., 2016/9524 E., 2016/9547 K., (www.lexpera.comtr Erişim Tarihi 15 Mayıs 2020).

55 Geiser (n 17) Art 397a N 14; Guillod (n 42) Art 426 N 65. 
sürdürmesi bakımından gerekli olan bakım hizmetlerinin sağlanması amacına yönelebilir ${ }^{56}$. Bir kişinin özgürlüğünün kısıtlanması hususunda karar verirken, özgürlüğün kısıtlanmasının kişinin hayatında yaratacağı olumlu ve olumsuz etkilerin birbirleri ile ölçülmesi gerekir. Bu aşamada, kişinin çevresinin ve toplumun özgürlüğün kısıtlanması suretiyle sağlayacağı faydanın ikinci planda kalması gerekir. Yoksa bunlar tek başına özgürlüğün kısıtlanması sebebi olarak dikkate alınamazlar ${ }^{57}$.

Kanunda sayılan zayıflık sebepleri ile kişisel korumaya ihtiyaç duyan kişinin bizzat kuruma başvurması veya kurumda kalmayı talep etmesi halinde, koruma amacıyla özgürlüğün sınırlanması gerekmez. Söz konusu hallerde kişinin bizzat bu taleplerde bulunması, korunması için özgürlüğünün kısıtlanmasının gerekli olmadığ 1 anlamına gelir ${ }^{58}$. Ancak kişinin kendi isteği ile kuruma yerleştirilmesi veya kurumda bulundurulmaya devam edilmesinden söz edebilmek için, ayırt etme gücüne sahip olmasi gerekir ${ }^{59}$.

Koruma amacıyla gerçekleşecek olan özgürlük kısıtlamasının kişisel koruma ihtiyacının devam ettiği süre ile sınırlı olması da yine ölçülülük ilkesinin gereğidir ${ }^{60}$. Nitekim TMK m 432/II hükmü, kişinin, durumu elverir elvermez kurumdan çıkarılacağını düzenlemiştir. Bu sebeple hakim, özgürlüğün kısıtlanması halini belirli bir süreyle sınırlayamayacağı gibi, kişi özgürlüğünün ömür boyu kısıtlanmasına da hükmedemez ${ }^{61}$. Kanun koyucu, özgürlüğün kısıtlanacağı süre bakımından zayıflık halinin devamı şartını aramıştır. İlgili kişinin durumu elverir elvermez kurumdan çıkarılacağı açıkça düzenlenmiştir (TMK m 432/III).

\section{Kişinin ihtiyaç duyduğu kişisel korumanın tedavi, ĕğitim, islah veya bakıma yönelik olmast}

Türk Medeni Kanunu m 432 hükmünde, ilgili kişinin, tedavisi, eğitimi veya ıslahı için bir kuruma yerleştirilebileceği veya orada alıkonabileceği ifade edilmiştir. Bununla birlikte bir kişinin tedavi, eğitim veya ıslah edilmesi dışında yalnızca bakımı için bir kuruma yerleştirilmesi de mümkün olmalıdır. Kişisel koruma, kişinin, insan onuruna yakışan bir yaşam sürmesi için gereken her türlü tedbiri kapsar ${ }^{62}$. Buna göre, beslenme, vücut temizliği, giyim ve hatta asgari nitelikte uğraş veya iş bulma dahi bu kapsamda görülebilecektir ${ }^{63}$. O nedenle, kişinin bakımı için bir kuruma

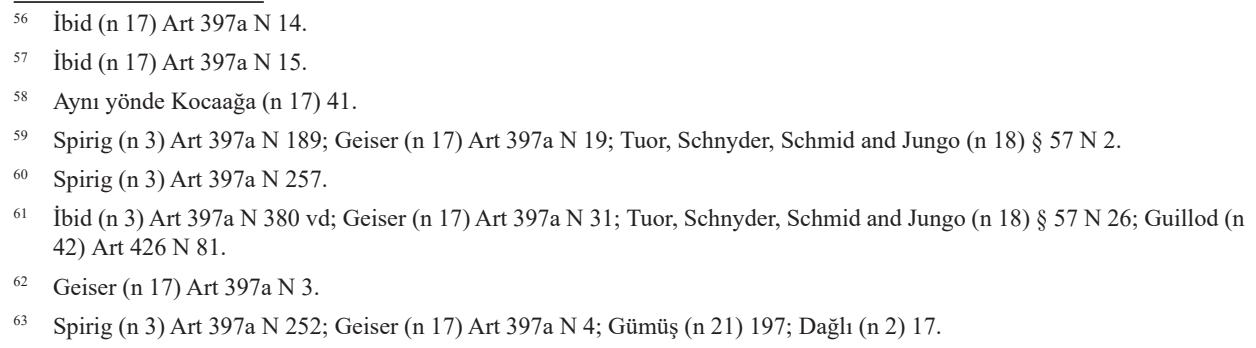


yerleştirilmesi de, her ne kadar bakım ${ }^{64}$ madde hükmünde sayılmamış olsa da, mümkün görülmelidir ${ }^{65}$.

Kişinin yerleştirildiği kurumda alıkonulabilmesi, TMK m 432 hükmünde sayılmış olan zayıflık hallerinin devam etmesine bağlıdır. Kişisel korumanın türü, süresi ve ne tür bir kurumda gerçekleşeceği, bütünüyle somut olayın şartlarına bağlıdır. $\mathrm{O}$ nedenle, kişisel koruma tıbbi tedavi, eğitim veya bakımın yanı sıra, kişisel uğraş sağlanması veya korunması hedeflenen kişinin gereksinim duyduğu temel ihtiyaçların karşılanması suretiyle de gerçekleşebilir ${ }^{66}$.

Koruma amacıyla özgürlüğün kısıtlanmasının amacı, kişinin yeniden kendi sorumluluğunu taşıyabilecek bağımsız bir insan olmasını sağlamak, en azından yaşamını insan haysiyetine yakışır bir şekilde devam ettirmesini temin etmektir. Ayrıca, kişinin kurum dışında yaşamaya tekrar yetkin kılınmasının gerektiği de ifade edilmektedir ${ }^{67}$. Bunun mümkün olmaması halinde ise ilgilinin kendisine sağlanan koruma vasıtasıyla insan onuruna yakışır bir yaşam sürmesi hedeflenmelidir ${ }^{68}$.

\section{Kişinin toplum için tehlike oluşturması}

Kanun koyucu, TMK m 432 hükmünde sayılan zayıflık sebeplerinden biri sebebiyle korumaya ihtiyaç duyan kişi bakımından ayrıca, "toplum için tehlike oluşturma" şartını aramıştır. Oysa koruma amacıyla özgürlüğün kısıtlanması ile hedeflenen, toplumun korunması değil, madde hükmünde sayılan sebeplerden biri dolayısıyla zayıflık hali içinde bulunan ve bu sebeple kişisel korumaya ihtiyaç duyan kişinin korunması olmalıdır ${ }^{69}$. Burada toplumun korunması, tali bir öneme sahiptir ${ }^{70}$. Hükmün, Medeni Kanun'un "Aile Hukuku” kitabının üçüncü kısmında yer alan "Vesayet" başlığı altında düzenlenmiş olması da, kişiye kişisel koruma sağlanması amacının ön planda tutulmasını gerektirir.

Sorunu bir örnek içinde nakletmek gerekirse; Bir kimsenin akıl hastalığı dolayısıyla kendi bakımını sağlayamadığını varsayalım. Bu halde kişinin vücut bütünlüğünün korunması bakımından yardıma ihtiyaç duyması söz konusu olsa dahi, kişi, toplum için tehdit oluşturmadığı sürece, özgürlüğünün kısıtlanması mümkün

\footnotetext{
Kurum kavramının geniş yorumlanması suretiyle bakımevi, yurt veya kliniklerin dahi kurum olarak yorumlanabileceği yönünde Dural, Öğüz ve Gümüş (n 31) N 2184; Elif Aydın Özdemir, '19.12.2008 Tarihli İsviçre Medeni Kanunu Değişikliği ile Karşılaştırmalı Olarak Türk Medeni Kanunu’nda Koruma Amacıyla Özgürlüğün Kısıtlanması Düzenlemesi’, (2013) XV (2) Dokuz Eylül Üniversitesi Hukuk Fakültesi Dergisi 191.

65 Krş Kilıçoğlu (n 1) 589.

66 İmamoğlu 'Zorla Tedavi' (n 17) 43.

67 Çavuşoğlu Işıntan (n 20) 302; Ayrıca bkz İmamoğlu 'Zorla Tedavi’ (n 17) 43; Akıntürk ve Ateş (n 1) 506.

68 Guillod (n 42) Art 426 N 54.

69 Dural, Öğüz ve Gümüș (n 31) N 2179; Öztan (n 7) 1358; Çavuşoğlu Ișıntan (n 20) 298; Gümüș (n 21) 193; Kocaağa (n 17) 40.

70 Geiser (n 17) Art 397a N 3; Dural, Öğüz ve Gümüş (n 31) N 2179; Öztan (n 7) 1355, 1358; Aksi yönde Akıntürk ve Ateş (n 1) 508
} 
olmayacaktır ${ }^{71}$. Ancak bu somut sonuç, vesayet hukukunun ilke ve prensipleri ile bağdaşmamaktadır ${ }^{72}$. Koruma amacıyla kişi özgürlüğünün kısıtlanması bakımından önem arz eden, kişinin madde hükmünde sayılan sebepler dolayısıyla kişisel korumaya ihtiyaç duyması ve bu korumanın başka şekilde sağlanamaması şartlarıdır. Söz konusu şartların varlığı halinde ayrıca kişisel korumaya muhtaç olan kişinin toplum için tehlike oluşturmasını aramak, madde hükmünün amacına ulaşmasını engelleyecek ve hükmün kendi amacı ile çelişecektir ${ }^{73}$. Bu sebeple, öğretide "toplum için tehlike oluşturma" şartının TMK m 432 hükmünün uygulanması bakımından aranmaması gerektiği ileri sürülmektedir ${ }^{74}$.

Bununla birlikte farklı bir görüş, koruma amacıyla özgürlüğün korunmasında kişinin kendisinden ziyade, sebep olacağı tehlikeler karşısında üçüncü kişilerin korunmasının hedeflendiğini, özgürlüğü kısıtlanan kişinin bu korumadan dolayısıyla yararlandığını ifade etmektedir ${ }^{75}$.

Toplum için tehlike oluşturma şartının TMK m 432 hükmünün kapsamına, AY m 19/II hükmüne uyum sağlamak amacıyla getirildiği söylenebilir ${ }^{76}$. Çünkü AY m 19/II hükmünde kişinin korunması amacıyla özgürlüğünün sınırlanması halleri düzenlenirken de "toplum için tehlike teşkil eden" ifadesi kullanılmıştır. Bununla birlikte söz konusu Anayasa hükmü, doğrudan koruma amacıyla özgürlüğün korunması kurumuna dayanak teşkil etmesi amacıyla düzenlenmemiştir ${ }^{77}$. Bu husus Anayasa m 19/II hükmü ile ilgili Danışma Meclisi'nin gerekçesinden açıkça anlaşılmaktadır ${ }^{78}$. Gerekçede ilgili düzenlemenin amacı, suç işleme potansiyeline sahip olan kişilerin suç işlemelerine engel olmak amaciyla "Önleyici güvenlik tedbirleri", bir diğer ifadeyle "Toplumsal savunma tedbirleri" bakımından dayanak yaratılması olarak ifade edilmiştir. Nitekim yine gerekçede söz konusu tedbirlerin neler olacağının "Toplumsal Savunma Kanunlarl" tarafından düzenleneceğine işaret edilmiştir. O halde Anayasa m 19/II hükmünün amaçlarının koruma amacıyla özgürlüğün kısıtlanması kurumu ile yerine getirilmesi zaten mümkün değildir. Zira "önleyici güvenlik tedbirleri” ile güdülen amaç, vesayet tedbirleri ile güdülen amaçtan bütünüyle farklıdır ${ }^{79}$.

\footnotetext{
Ayrıca bkz Dural, Öğüz ve Gümüş (n 31) N 2179.

Aynı yönde ibid (n 31) N 2179.

İbid (n 31) N 2179; Öztan (n 7) 1359.

74 Dural, Öğüz ve Gümüş (n 31) N 2179; Öztan (n 7) 1358; Aksi yönde bkz Yarg.18. HD., 14.6.2016 T., 2016/9524 E., 2016/9547 K.; Yarg. 18. HD., 20.6.2016 T., 2016/6467 E., 2016/9883 K. (www.lexpera.comtr Erişim Tarihi 15 Mayıs 2020).

5 Dağlı (n 2) 9, 39.

76 Gümüş (n 21) 200; Kocaağa (n 17) 40

77 Gümüş (n 21) 201; Kocaağa (n 17) 40; Aydın Özdemir (n 64) 185 vd.

78 Bkz Madde Gerekçeli Türkiye Cumhuriyeti Anayasası, TBMM, $2008<$ https://acikerisimtbmmgov.tr/xmlui/bitstream/ handle/11543/1169/200901027.pdf?sequence=1\&isAllowed=y> Erişim Tarihi 12 Mayıs 2020; Konu hakkında ayrıca bkz "Girişé başlığı.

79 Gümüş (n 21) 201 vd; Aydın Özdemir (n 64) 185, 186; Ayrıca bkz Guillod (n 42) Art 426 N 57 vd.
} 
Kanun koyucunun Anayasa m 19/II hükmünde toplum için tehlike arz eden kimseler bakımından bu yönde bir düzenleme getirmiş olması, koruma amacıyla özgürlügüun korunması kurumunun düzenlenmesinde de mutlaka "toplum için tehlike oluşturma" şartının aranmasını zorunlu kılmaz ${ }^{80}$. Kanun koyucu, bir kişinin özgürlüklerinin toplum menfaati için kısıtlanmasına olanak tanımışsa bu halde, kişi özgürlüğünün kişinin bizâtihi korunması amacıyla kısıtlanmasına evleviyetle imkân tanımış olduğu kabul edilmelidir ${ }^{81}$. Dolayısıyla koruma amacıyla kişi özgürlüğünün kısıtlanması bakımından TMK m 432 hükmünde "toplum için tehlike oluşturma" şartının aranmaması, Anayasa m 19/II hükmüne aykırılık oluşturmazdı. Ayrıca, Avrupa İnsan Hakları Sözleşmesi, m 5 hükmünün (e) bendinde bu yönde bir şarta yer vermemiştir.

Toplum için tehlike oluşturma şartı bakımından akla gelen bir diğer husus, bu şartın ağır tehlike arz eden bulaşıcı hastalık bakımından getirilmiş olabileceğidir. Zira ağır tehlike arz eden bulaşıcı hastalık hallerinde kişinin özgürlüğünden mahrum bırakılması,kendisininkorunmasındanziyadehastalığınbulaşmasınınengellenmesiyle ilgilidir. Nitekim AİHS m 5, (e) bendinde açıkça, "bulaşıcı hastalıkların yayılmasını engellemek" amacından söz edilmektedir. Kaynak İsviçre Medeni Kanunu, mülga m 397a hükmünde olduğu gibi, yürürlükte olan İMK. m 426 hükmünde de özgürlüğü kısıtlanan kişi bakımından "toplum için tehlike oluşturmak" şartını aramamıştır. Ancak İsviçre Medeni Kanunu “ağır tehlike arz eden bulaşıcı hastalık” halini koruma amacıyla özgürlüğün kısıtlanması sebebi olarak da öngörmemiştir.

O halde, toplum için tehlike oluşturma şartının yalnızca ağır tehlike arz eden bulaşıcı hastalık bakımından aranması sonucuna, hükmün amaca uygun sınırlanması suretiyle varılması mümkündür. Zira nakledilen örnekte görüldüğü üzere, kişilik hakkının korunmasını, ilgili kişinin toplum için tehlike arz etmesi şartına bağlamak, hakkaniyete ve vesayet hukukunun temel ilkelerine aykırı sonuçlara yol açacaktır. $\mathrm{Bu}$ sebeple, kanun hükmünün örtülü boşluk içerdiğinden bahisle amaca uygun sınırlandırılarak, toplum için tehlike oluşturma şartının yalnız ağır tehlike arz eden bulaşıcı hastalık bakımından aranması söz konusu olabilir. Ayrıca bir vesayet tedbiri olan koruma amacıyla özgürlüğün kısıtlanması kurumuna kişinin üçüncü kişiler için tehlike arz etmesi halinde başvurulabiliyor olması, söz konusu şart olmaksızın sırf kişinin kendi kişiliğinin korunması için başvurulmasını evleviyetle kapsamalıdır. Nitekim Türk Medeni Kanunu, kişilik hakkını, bu hakkın kişinin kendisine karşı korunmasını da sağlayacak şekilde düzenlemiştir (TMK m 23).

\footnotetext{
80 Kişi özgürlüğüne koruma amacıyla yapılacak olan müdahalenin TMK m 23 ve 24 hükümleri çerçevesinde, kişilik hakk1 zedelenen kişinin rızası veya üstün nitelikte özel yarar hukuka uygunluk sebebine dayanacağı yönünde Aydın Özdemir (n 64) 188

81 Gümüș (n 21) 202.
} 
Bu kapsamda önerilebilecek bir diğer çözüm ise "toplum için tehlike oluşturma şartı”nın dar yorumlanmasıdır. Bir kimsenin toplum için tehlike oluşturmasının mutlaka toplumun diğer fertlerine suç olarak nitelendirilebilecek davranışlarda bulunma ihtimali olarak anlaşılmaması gerekir. Toplumun, kendi bakımını, tedavisini, eğitimini ve kişisel ihtiyaçlarını karşılayamayan fertlerine yardım edilmesi, daha sağlıklı ve eğitimli bir toplumun yaratılmasına yol açar. $\mathrm{Bu}$ kişilerin yardımsız bırakılması ise toplumun zararına yol açar. Dolayısıyla kişilerin insan onuruna yakışır bir yaşam sürmesi için kişisel korumadan mahrum bırakılması, başlı başına toplumu tehlikeye atabilecek bir unsur olarak değerlendirilmelidir.

\section{Kişinin çevresine getirdiği külfetin aşırı olmast}

Koruma amacıyla özgürlügün kısıtlanmasında aranacak bir diğer şart ise kişinin çevresine getirdiği külfettir. Kişinin çevresine getirdiği külfet ile kast edilen, başlı başına kişinin çevresine karşı suç teşkil eden davranışları gerçekleştirme eğiliminde olup olmadığı değildir ${ }^{82}$. Bir kimsenin suç işlemekten korunması da, söz konusu kişinin kişiliğinin korunmasına hizmet eder. Ancak bu halde kişiye karşı öncelikle ceza hukukundan doğan tedbirlerin uygulanıp uygulanamayacağı önemlidir ${ }^{83}$. Şayet bu yönde uygulanabilecek etkili bir tedbir yoksa o halde, kişinin suç işlemekten korunması, suç işleme eğiliminin kanunda sayılan zayıflık sebeplerinden kaynaklanması şartıyla, koruma amacıyla özgürlüğün kısıtlanması tedbirinin uygulanmasıyla gerçekleşebilir. Ancak burada amaç, öncelikle kişinin kendisinin korunması olmalıdır. Bu halde de özgürlüğün kısıtlanması tedbiri, ancak kişinin korunması ihtiyacı ile ölçülü olması şartıyla uygulanabilir.

"Kişinin çevresi” kavramına, korunmak istenen kişinin içinde bulunduğu zayıflık halinden etkilenen kişiler dâhildir. Kişinin ailesi, yakınları ve komşuları bu anlamda örnek verilebilir ${ }^{84}$. Kişinin çevresine getirdiği külfetin aşırı olup olmadığı, söz konusu kişilerin özgürlüğü kısıtlanacak olan kişinin korunması için yaptıkları fedakârlıklar dikkate alınarak tespit edilmelidir. Bu halde, söz konusu korumanın kişinin çevresine dâhil olan kimselerin ekonomik ve sosyal değerleri üzerindeki etkisinin aşırı olup olmadığına bakılmalıdır ${ }^{85}$. Külfete katlanma ölçüsünün tayininde, özgürlüğü kısıtlanacak kişinin söz konusu kişilerle olan yakınlık derecesi önem arz eder. Bir kişinin korunması gereken kişiyle ilgili ne kadar bir külfete katlanmasının gerektiği, yakınlık derecesine göre farklılık gösterir ${ }^{86}$. Bunun sebebi, koruma amacıyla özgürlüğü kısıtlanacak olan kişinin çevresinde bulunan kişilerin kendisine bakma

\footnotetext{
Spirig (n 3) Art 397a N 339, 341 vd; Geiser (n 17) Art 397a N 26.

Spirig (n 3) Art 397a N 344.

84 İbid (n 3) Art 397a N 359; Geiser (n 17) Art 397a, N 27; Kocaağa (n 17) 42; İmamoğlu 'Zorla Tedavi' (n 17) 44; Çevre ifadesinin kapsamına ilgili kişi ile sürekli bir ortam birlikteliği içinde olan insanların girdiği yönünde bkz Akıntürk ve Ateş (n 1) 508 .

85 Spirig (n 3) Art 397a N 350; Gümüş (n 21) 196 vd; Akıntürk ve Ateş (n 1) 508.

86 Çavuşoğlu Işıntan (n 20) 299; Kocaağa (n 17) 42 vd.
} 
yükümlülüğünün kapsamının yakınlık derecesine göre tayin edilmesidir. Koruma amacıyla özgürlüğün sınırlanması bakımından kişinin çevresine getirdiği külfetin dikkate alınabilmesi için, bu külfetin aşırı olması gerekmektedir ${ }^{87}$.

Bu kapsamda, kişinin korunması için sarf edilmesi gereken emek ve malvarlığı değerinin katlanılabilir olduğunun tespit edilmesi, söz konusu kişinin özgürlüğünün koruma amacıyla kısıtlanamayacağı anlamına gelmez. Zira burada asıl önemli olan husus, ilgilinin çevresi tarafından alınan tedbirlerin, korunması bakımından yeterli olup olmadığıdır. Dolayısıyla kişi her ne kadar çevresine aşırı derecede külfet getirmese de, şayet ilgilinin çevresi tarafından alınabilen tedbirler kişiyi korumaya elverişli değilse o halde, yine de ilgilinin bir kuruma yerleştirilmesi veya orada alıkonulması gerekli olabilir. Bunun yanı sıra, kişinin çevresine getirdiği külfetin aşırı olması da, tek başına söz konusu kişinin özgürlüğünün kısıtlanmasını gerektirmez. Şayet kişiyi kuruma yerleştirmeden, örneğin sosyal yardım imkânı var ise bu imkândan yararlanılarak çevrenin katlanması gereken külfet hafifletilebiliyorsa kişinin özgürlüğünün kısitlanmasına gerek kalmaz. Görüldüğü üzere, kişinin çevresine getirdiği külfetin aşırı olmas1 şartı, özgürlüğün kısıtlanması için kişinin başka türlü korunamaması gerektiğine işaret eden ölçülülük şartı ile birlikte değerlendirilmelidir ${ }^{88}$.

Sonuç olarak, özgürlüğü kısıtlanacak olan kişinin çevresine getirdiği külfetin tali bir unsur olduğu ifade edilmelidir ${ }^{89}$. Kişinin çevresine getirdiği külfetin aşırı olması, tek başına özgürlüğün kısıtlanmasını gerektirmediği gibi, diğer şartların varlığı halinde, kişinin çevresine aşırı külfet getirmesi söz konusu olmasa dahi, özgürlüğün k1sıtlanması söz konusu olabilir ${ }^{90}$.

\section{Kişinin ihtiyaç duyduğu kişisel korumayı sağlayabilecek bir kurumun bulunmast}

Koruma amacıyla kişi özgürlüğünün kısıtlanmasının sebebi, kişiye ihtiyaç duyduğu korumanın, bu korumayı sağlamaya elverişli bir kurum vasıtasıyla sağlanmasıdır. $\mathrm{Bu}$ halde kurum, özgürlüğü kısıtlanan kiş̧iye gereksinim duyduğu korumanın sağlanacağı yer olarak tarif edilebilir ${ }^{91}$. Kurum kavramının geniş yorumlanarak, kişinin geçerli bir iradesi olmadan, hürriyetinin hissedilebilir şekilde kısıtlanması suretiyle, ihtiyaç duyduğu korumanın sağlandığı her yerin kurum olarak nitelendirilmesi savunulmaktadır ${ }^{92}$. Kişinin kurumu dilediği zaman terk edememesi, yeterli görülmektedir. Yoksa kurumun mutlaka giriş ve çıkışlarının cezaevlerine

\footnotetext{
7 Dural, Ögüz ve Gümüş (n 31) N 2174.

8 Aydın Özdemir (n 64) 189.

Spirig (n 3) Art 397a N 339; Geiser (n 17) Art 397a N 26; Öztan (n 7) 1358; Kocaağa (n 17) 43.

$90 \quad$ Spirig (n 3) Art 397a N 11, 339, 340; Geiser (n 17) Art 397a, N 26; İmamoğlu 'Zorla Tedavi' (n 17) 44.

91 Kavram hakkında ayrıca bkz Dural, Öğüz ve Gümüş (n 31) N 2184.

92 Spirig (n 3) Art 397a N 119; Geiser (n 17) Art 397a N 22; Tuor, Schnyder, Schmid and Jungo (n 18) § 57 N 17; Dural, Öğüz ve Gümüş (n 31) N 2184; Gümüş (n 21) 206.
} 
benzer şekilde kontrol edilmesi şart koşulmamalıdır ${ }^{93}$. Bu halde kurum, bakımevi, huzurevi, yurt, klinik vb. yerler olabilir ${ }^{94}$.

Kanun koyucu TMK m 432 hükmünde kurum bakımından "elverişlilik" şartını aramıştır ${ }^{95}$. Kurum bakımından elverişlilik şartının yerine gelmiş olup olmadığı, somut olayın özellikleri kapsamında dikkatle incelenmelidir. Hâkim, her bir somut olayda elverişli olan kurumu, somut olayın özellikleri dairesinde belirlemelidir ${ }^{96}$. Elverişli kurum ile kast edilen, kişinin ihtiyaç duyduğu kişisel korumayı sağlayabilecek nitelikte organizasyon ve personele sahip kurumdur ${ }^{97}$.

Kişinin korunması amacıyla özgürlüğünün kısıtlanmasına dair verilen kararda elverişli kurumun ismen belirlenmiş olması gerekir. Aksi takdirde, söz konusu karar, kurumun elverişli olup olmadığı hususunda denetime tabi tutulamaz ve icra edileme ${ }^{98}$. O sebeple, elverişli kurumun belirlenmemiş olması durumunda koruma amacıyla özgürlügün kısıtlanmasına dair kararın maddi anlamda kesin hüküm oluşturduğundan söz edilemez ${ }^{99}$. Öğretide, hâkimin karar vermeden önce tespit etmiş olduğu kuruma ilgili kişinin kabul edilip edilmeyeceği hususunu sorması gerektiği ifade edilmektedir. Aksi takdirde ilgili kurumun özgürlüğü kısıtlanmış olan kişiyi kabul etmemesi, kararın icra edilememesine yol açacaktır ${ }^{100}$. Bununla birlikte kişi özgürlüğünün ilgili kurumun özgürlüğü kısıtlanacak olan kişiyi kabul etmesi şartına bağlı olarak kısıtlanması da mümkün görülmektedir ${ }^{101}$.

Kişiselkorumanıngerçekleşmesinisağlayabilecekuygunbirkurumunbulunmaması, kişinin özgürlügünün kısıtlanmasına karar verilmesini engelleyecektir ${ }^{102}$. Bununla birlikte elverişli bir kurumun varlığından söz edebilmek için, özgürlüğü kısıtlanmak istenen kişinin temel sorunlarına ve ihtiyaçlarına cevap verebilecek nitelikte bir kurumun bulunması yeterli görülmelidir. Yoksa ideal bir kurumun bulunması aranmamalıdı1 $^{103}$. O halde diyebiliriz ki koruma amacıyla özgürlüğün kısıtlanması tedbirinin kendisinden beklenen faydayı sağlaması, ancak ülkede kişisel korumayı sağlayabilecek elverişli kurumların bulunması şartıyla mümkündür.

\footnotetext{
3 Spirig (n 3) Art 397a N 119, 120; Geiser (n 17) Art 397a N 22; Tuor, Schnyder, Schmid and Jungo (n 18) § 57 N 17; Guillod (n 42) Art 426 N 68.

94 Geiser (n 17) Art 397a N 23; Tuor, Schnyder, Schmid and Jungo (n 18) § 57 N 17; Dural, Öğüz ve Gümüş (n 31) N 2184; Gümüş (n 21) 206.

95 Kurumun elverişli olması şartının ölçülülük prensibinin gereği olduğu hususunda Guillod (n 42) Art 426 N 67.

96 Spirig (n 3) Art 397a N 130; Dural, Ögüz ve Gümüş (n 31) N 2186; Gümüş (n 21) 207.

97 Spirig (n 3) Art 397a N 123; Geiser (n 17) Art 397a N 24; Dural, Öğüz ve Gümüş (n 31) N 2186; İmamoğlu 'Zorla Tedavi' (n 17) 44

98 Spirig (n 3) Art 397a N 125; Dural, Öğ̈̈z ve Gümüş (n 31) N 2187.

99 Dural, Öğ̈̈z ve Gümüş (n 31) N 2187.

100 Geiser (n 17) Art 397a N 24.

101 İbid (n 17) Art 397a N 24.

102 Spirig (n 3) Art 397a N 131; Geiser (n 17) Art 397a N 25; Tuor, Schnyder, Schmid and Jungo (n 18) § 57 N 17; Dural, Öğüz ve Gümüş (n 31) N 2187; Gümüş (n 21) 208; Kocaağa (n 17) 42; İmamoğlu 'Zorla Tedavi' (n 17) 44.

103 Geiser (n 17) Art 397a N 25; Tuor, Schnyder, Schmid and Jungo (n 18) § 57 N 17.
} 


\section{Koruma Amacıyla Özgürlüğün Kısıtlanmasının Sonuçları ve Zorla Tedavi Sorunu}

\section{Koruma Amacıyla Özgürlüğ̈̈̈n Kısıtlanmasının Sonuçları}

Bir kimsenin TMK m 432 vd hükümleri uyarınca özgürlüğünün kısıtlanması, söz konusu kişinin, tedavisi, eğitimi veya ıslahı için elverişli bir kuruma yerleştirilmesi sonucunu doğurur. Kişinin zaten böyle bir kurumda bulunması halinde, özgürlüğün kısıtlanması kararı, ilgilinin bulunduğu kurumda alıkonulmasına yol açar.

Bir kişinin korunması amacıyla özgürlüğünün kısıtlanabilmesi, ancak hâkim kararı ile olabilir. Koruma amacıyla özgürlügüün kısıtlanmasına TMK m 420 kapsamında geçici bir önlem olarak hükmedilemez ${ }^{104}$. Kişinin korunması amacıyla geçerli bir iradesi olmaksızın belirli bir kuruma yerleştirilmesine veya orada alıkonulmasına karar verecek olan yetkili makam, kişinin yerleşim yerindeki vesayet makamıdır (TMK m 433). Bununla birlikte gecikmesinde sakınca bulunan hallerde kişinin bulunduğu yer vesayet makamının da söz konusu kararı vermesi mümkündür. Aşağıda açıklanacak olan şartların gerçekleşmiş olduğu sonucuna varan hâkim, kişinin özgürlügünün koruma amacıyla kısıtlanması hususunda karar vermek zorundadir ${ }^{105}$.

Kişisel korumayı gerektiren durumun sona ermesi halinde kişi, yerleştirildiği veya alıkonulduğu kurumdan çıkarılmalıdır. Kanun koyucu, ilgili kişinin durumu elverir elvermez kurumdan çıkarılmasını emretmiştir (TMK m 432/III). Kişinin kurumdan çıkarılmasına koruma amacıyla özgürlügüün kısıtlanmasına dair kararı veren vesayet makamı karar verir. Koruma amacıyla özgürlügün kısıtlanması için aranan şartların ortadan kalkması halinde kişinin kurumdan çıkarılması, her zaman talep edilebilir ${ }^{106}$. Vesayet makamı, çıkarmaya re'sen de karar verebilmelidir ${ }^{107}$. Söz konusu talep, özgürlüğü kısıtlanan kişi tarafından yöneltilebileceği gibi, onun yakınları tarafından da yöneltilebilmelidir. İlgili kişinin kurumdan çıkarılma talebinde bulunabilmesi, ayırt etme gücüne sahip olmasına bağlıdır. Kanun koyucu, özgürlüğün kısıtlanması ve kurumdan çıkarılma kararlarına karşı özgürlüğü kısıtlanan kişinin yanı sıra, yakınlarının da itiraz edebilmesini mümkün kılmıştır (TMK m 435). Bu halde, yakınların ilgili kişinin kurumdan çıkarılmasını talep edebileceklerinin de kabulü gerekir. Yakın kavramının kapsamına özgürlüğü kısıtlanan kişi ile fiili ilişki içerisinde olan kişiler dâhildir ${ }^{108}$. Bu anlamda ilgili kişi ile yakın bir ilişki içinde olan, söz konusu kişi ile aralarında güven ilişkisi kurulmuş olan, ilgili kişiye olan yakınlığı ve karakteristik özellikleri itibariyle

\footnotetext{
$\overline{104}$ Geiser (n 17) Art 397a N 16; Spirig (n 3) Vorb zu Art 397a-397f N 49 vd.

105 Spirig (n 3) Art 397a N 19; Tuor, Schnyder, Schmid and Jungo (n 18) § 57 N 20.

106 Tuor, Schnyder, Schmid and Jungo (n 18) § 57 N 27; Guillod (n 42) Art 426 N 78 vd.

107 Guillod (n 42) Art 426 N 81.

108 Tuor, Schnyder, Schmid and Jungo (n 18) § 57 N 27.
} 
ilgili kişinin menfaatlerinin korunması hususunda dikkate alınması gereken kişiler, “yakın” olarak kabul edilmelidir ${ }^{109}$. İsviçre Medeni Kanunu, 19 Aralık 2008 tarihli Kanun ile gerçekleşen revizyonla birlikte, ilgili kişinin kendisinin ve yakınlarının her zaman kurumdan çıkarılma kararı verilmesini talep edebileceklerini açıkça düzenlemiş̧ir. İlgili hükümde bu yönde bir talep hakkında gecikmeksizin karar verilmesi gereği de öngörülmüştür (İMK. m 426/IV) ${ }^{110}$. Türk Hukuku'nda bu yönde açık bir düzenleme olmamakla birlikte, TMK m 432/III hükmü icabı, aynı esasın Türk Hukuku'nda da kabulü gerekir.

Bunun yanı sıra ilgili kişinin yerleştirildiği veya alıkonulduğu kurumun yetkili kişileri de vesayet makamına başvurarak kısıtlamanın kaldırılmasını talep edebilmelidirler ${ }^{111}$. İlgili kişinin kurumdan çıkarılmasının talep edilmesi halinde hâkim, kural olarak kişinin kaldığı kurumun görüşüne de başvurmalıdır. Ancak hâkim, kurumun kişisel koruma ihtiyacının sona ermiş olduğu hususundaki görüşü ile bağlı değildir. Bunun yanı sıra hâkimin bu hususta karar verme yetkisini ilgili kuruma devretmesi de mümkün değildir ${ }^{112}$. Kişinin bulunmakta olduğu kurumun değiştirilmesi, kural olarak hâkim kararı ile mümkün olmak gerekir ${ }^{113}$. Bununla birlikte kişi bakımından tayin edilen yeni kurumun özgürlüğü daha az oranda sınırlaması söz konusu ise bu halde, istisnaen hâkim kararı aranmayacağı öğretide kabul edilmektedir ${ }^{114}$.

İlgili kişinin dini bayramlarda veya özel günlerde kurum dışında zaman geçirmesine bulunduğu kurum tarafindan izin verilmesi mümkündür. Böyle bir izin, koruma amacıyla özgürlüğün kısıtlanmasını ortadan kaldırmaz. Bu durumda ilgilinin kuruma geri dönmemesi söz konusu olursa koruma amacıyla özgürlüğün kısıtlanması için

109 İbid (n 18) § 50 N 26; Guillod (n 42) Art 426 N 93; Ayrıca bkz BGer 5A_837/2008, 5.2. numaralı gerekçe, (www.bger.ch Erişim Tarihi 28 Mayıs 2020)

110 İsviçre Medeni Kanunu, 19 Aralık 2008 tarihli Kanun ile getirilmiş olunan m 432 hükmüyle, özgürlüğü kısıtlanan herkesin güvendiği bir kişiyi seçerek, kurumda bulunduğu sürece ve özgürlüğün kısıtlanması ile ilgili süreç sona erene kadar, seçtiği bu kişiden destek alabileceği düzenlenmiştir. Kanun koyucu, söz konusu kişiyi "Vertrauensperson" olarak nitelendirmiş olup, bu nitelendirmenin Türkçe karşılığı olarak "güvenilir kişi”" kavramı kullanılabilir. Özgürlügü koruma amacıyla kısıtlanan kişi, kişiye sıkı sıkıya bağlı bir hak olması dolayısıyla "güvenilir kişiyi” bizzat seçmelidir. Bu kişinin işin niteliği gereği gerçek kişi olması gerektiği kabul edilmektedir. Bkz Tuor, Schnyder, Schmid and Jungo (n 18) § $57 \mathrm{~N}$ 56. Güvenilir kişi, bu görevi kural olarak ivazsız ifa edecektir. Ancak özgürlüğü kısıtlanan kiși, bu görevi ivazsız yapacak kimse bulamazsa ve bunun karşılığında ivaz ödeyecek maddi olanaklara da sahip değilse bu halde, özgürlügü kısıtlanan kişiye vasi atanır. Tuor, Schnyder, Schmid and Jungo (n 18) § 57 N 56. Güvenilir kiși, özgürlüğün kısıtlanması ile ilgili prosedür sona erene kadar ilgili kişiyi hakları ve yükümlülükleri konusunda bilgilendirmek, ilgili kişinin taleplerini formüle ederek yetkili makama iletmek, uyușmazlıkların çözümünde yardım etmek ve ilgili kișiye süreç sona erene kadar refakat etmekle yükümlüdür. Kişinin tedavi edilmesinin gerektiği hallerde güvenilir kişi, tedavi planının hazırlanmasına da katılır. Bunun yanı sıra tedavinin esasları hakkında ve özellikle zorla tedavi gerçekleșecek ise tedavi hakkında, güvenilir kişinin bilgilendirilmesi gerekir (IMK. m 433, 434). Bunlar dışında güvenilir kişi, özgürlüğü kısıtlanan kişinin yakınına tanınmış olan hakları da kullanabilecektir. Bkz Tuor, Schnyder, Schmid and Jungo (n 18) § 57 N 57. Güvenilir kișinin sorumluluğunun kapsamı ise vesayete ilişkin hükümler arasında düzenlenmemiştir.Güvenilir kişinin hak ve borçlarının vekalet sözleşmesi veya vekaletsiz iş görmeye ilişkin hükümler kapsamında tayin edileceği kabul edilmektedir. Bkz Tuor, Schnyder, Schmid and Jungo (n 18) §57 N 58.

111 Kocaağa (n 17) 53; Aydın Özdemir (n 64) 205.

112 Dural, Öğ̈̈z ve Gümüş (n 31) N 2188.

113 Geiser (n 17) Art 397a N 32 vd; Tuor, Schnyder, Schmid and Jungo (n 18) § 57 N 18; Guillod (n 42) Art 426 N 76; Aksi yönde BGE 122 I 18, s. 35 (www.bger.ch Erişim Tarihi 20 Mayıs 2020)

114 Geiser (n 17) Art 397a N 32 vd. 
yeni bir karar alınması aranmaz. İlgilinin kuruma zorla getirilmesi, özgürlügünün kısıtlanması hususunda verilmiş olunan karara dayanarak sağlanacaktır ${ }^{115}$.

Kişinin kurumda geçirmesi gereken sürenin kademeli olarak azaltılması mümkündür. $\mathrm{Bu}$ nitelikte bir karar da ilgilinin kurumdan tamamen çıkarılması anlamına gelmediği için ayrıca karar alınmasını gerektirmez ${ }^{116}$.

İsviçre Medeni Kanunu, 19 Aralık 2008 tarihli Kanun vasıtasıyla değiştirilmiş olan m 431 hükmü ile, koruma amacıyla özgürlüğü kısıtlanan kişinin durumunun belirli aralıklarla denetlenmesi yükümlülügünü getirmiştir. Bu denetimi yapacak olan kişi, ilgilinin özgürlüğünün kısıtlanması hususunda karar vermeye yetkili olan yetişkinleri koruma makamıdır. Söz konusu hükme göre, ilk denetimin en geç ilgili kişinin kuruma yerleştirilmesinden veya orada alıkonulmasından sonraki altı ay içinde yapılması gerekmektedir. Bundan sonraki diğer denetimin ise ilk denetimden itibaren altı ay içerisinde yapılması öngörülmüştür. İkinci denetimden sonra hangi aralıklarla denetim yapılacağ 1 ise yılda en az bir defa olması şartıyla, somut olayın özelliklerine göre tayin edilecektir. Kanun koyucu, ikinci denetimden sonraki diğer denetimlerin gerekli sıklıkta yapılmasını öngörmüştür ( İMK. m 431/II). Denetimler ile hedeflenen, koruma amacıyla özgürlüğün korunması şartlarının ortadan kalkmış olup olmadığı ile kurumun hala elverişli olup olmadığı hususlarının tespitidir. Yetkili makam, söz konusu denetimi ilgili kişinin veya yakınlarının talebi olmasa da re'sen yapmakla yükümlüdür ${ }^{117}$. Denetimin detaylı yapılması ve esaslı noktaları gözden geçirmeye yönelik olması gerektiği kabul edilmektedir ${ }^{118}$. Bunun yanı sıra ilgili kişinin kurum içinde ayrıca bir odada izole edilmesi gibi tedbirler alınmışsa bu tedbirlerin gerekliliklerinin de aynı denetimde gözden geçirilmesi öngörülmektedir ${ }^{119}$. Söz konusu düzenleme, özgürlüğün kısıtlanması tedbirinin işlevini yerine getirmesinin yanı sıra ayrıca ilgilinin kişilik hakkının korunmasını da teminat alına almaktadır.

Koruma amacıyla özgürlüğün kısıtlanması, bir kişinin rızası hilafına bir kuruma yerleştirilmesi veya bulunduğu kurumda alıkonulması sonuçlarına yol açmaktadır. Bunun dışında kişinin söz konusu kurumdaki hareket özgürlüğünün sınırlandırılması bakımından Türk Medeni Kanunu herhangi bir düzenleme içermemektedir. Kural, kişinin yerleştirildiği kurumda hareket özgürlüğünün ve diş dünyayla olan ilişkisinin kısıtlanmamasıdır ${ }^{120}$. Hareket özgürlüğü, kişilik hakk1 kapsamında koruma gören özgürlüklerden olması itibariyle, sınırlanması, açık bir yasa hükmünün varlığını gerektirir. Ayrıca bu tür bir sınırlamanın da yine ölçülük presibine uygun şekilde

\footnotetext{
115 Guillod (n 42) Art 426 N 83.

116 İbid (n 42) Art 426 N 85.

117 Tuor, Schnyder, Schmid and Jungo (n 18) § 57 N 52.

118 İbid (n 18) § 57 N 52.

119 İbid (n 18) § 57 N 52.

120 Guillod (n 42) Art 426 N 69.
} 
gerçekleşmesi şarttır ${ }^{121}$ Yoksa burada TMK m 24/II hükmü kapsamında üstün nitelikte özel ya da kamusal yarar kavramlarından yola çıkılarak kişinin hareket özgürlüğünün sınırlandırılması söz konusu olamaz. Nitekim hem AİHS m 5/I hükmü hem de AY m 19/II hükmü, usul ve esasların yasa ile düzenlenmiş olmasını öngörmüştür. $\mathrm{Bu}$ tür bir tedbirin şartları ve usulü, bir kanun hükmü ile düzenlenmek suretiyle, kişilik hakkı, söz konusu tedbirler kapsamında koruma altına alınmalıdır. Bu hali ile TMK m 24/II hükmünde kişi özgürlüğünün sınırlandırılması bakımından usul ve esasların düzenlenmemiş olması itibariyle, söz konusu hüküm, kişi hürriyetinin sınırlandırılması aşamasında yasallık şartını yerine getirmeye elverişli bir hüküm olarak değerlendirilemez.

Hareket özgürlügünün sınırlandırılmasından kasıt, bedensel hareket imkânlarının sınırlandırılmasıdır ${ }^{122}$. Buhalde, elektronik gözetleme tedbirleri, kapıların kilitlenmesi, kişinin yatağa bağlanması gibi tedbirler hareket özgürlüğünün sınırlandırılmasına yönelik tedbirlere örnek verilebilir ${ }^{123}$.

İsviçre Medeni Kanunu m 438 hükmünde, ilgili kişinin bulunduğu kurumda hareket özgürlügünün sınırlanmasına dair esaslar bakımından İMK. m 383 vd hükümlerine atıfta bulunulmuştur. Kendisine atıf yapılan IMK. m 383 vd hükümleri ise yurtlarda veya bakımevlerinde kalan, ayırt etme gücünden yoksun kimselerin bu yerlerdeki hareket özgürlüklerinin hangi şartlar altında sınırlanabileceğine ilişkin olup, ayrıca ilgili kişinin ve yakınlarının bu tür kısıtlamalara karşı sahip oldukları itiraz hakkını da düzenlemektedir. Kanun koyucu, bakım evlerinde kalan ayırt etme gücü olmayan kimselerin kendilerinin veya üçüncü kişilerin yaşam ve vücut bütünlükleri bakımından ciddi tehlike oluşturmaları ya da ortak yaşamı ağır bir şekilde engellemeleri hallerinde, bakımevinde kalan kimselerin ölçülülük ilkesine uymak şartıyla hareket özgürlüklerinin sınırlanabileceğini düzenlemiştir (IMMK. m $383)^{124}$. Söz konusu hükümler arasında yer alan m 386 hükmüyle, özgürlügü̈ kısıtlanan kişinin kişilik hakkının korunması gereği ayrıca ifade edilmiştir. Kanun koyucunun İMK. m 438 hükmünde $\mathrm{m} 383$ vd hükümlerine yapmış olduğu atıf sebebiyle, koruma amacıyla özgürlüğü sınırlanmış olan ayırt etme gücünden yoksun kimseler hakkında kurum içindeki hareket özgürlüğünün sınırlandırılması amacıyla alınacak tedbirler de ayn esaslara tabidir ${ }^{125}$.

\footnotetext{
21 Selma Hülya İmamoğlu, 'İsviçre Medeni Kanununun Yurtlarda veya Bakım Kurumlarında Kalan Ayırt Etme Gücü Bulunmayan Kişiler Hakkındaki Hükümleri Ve Türk Hukuku Açısından Değerlendirilmesi’, (2019) LXVIII (1) Ankara Üniversitesi Hukuk Fakültesi Dergisi 225.

122 İmamoğlu (n 121) 226.

123 İbid (n 121) 227.

124 Söz konusu İsviçre Medeni Kanunu m 383 vd hükümleri hakkında ayrıntılı bilgi için bkz İmamoğlu (n 121) 217 vd.

125 Ayrıntılı bilgi için bkz Tuor, Schnyder, Schmid and Jungo (n 18) §57 N 50 vd.
} 
Türk Hukuku'nda bu yönde bir düzenleme olmamakla birlikte, ilgili kişinin kurum içindeki hareket özgürlüğünün kısıtlanması bakımından aynı sonuçlara varmak gerekecektir. İMK. m 438 hükmünün atfiyla uygulama alanı bulan İMK. m 383 hükmünün vardığı sonuç, esasen ölçülülük prensibi vasıtasıyla yapılacak olan bir değerlendirmeyle varılması gereken sonucun aynısıdır. İlgiliye kurum içinde ne şekilde muamele edileceği, ilgilinin içinde bulunduğu koruma ihtiyacına göre belirlenmek gerekir. Dolayısıyla bu ihtiyaca hizmet etmeyen veya bu ihtiyaç ile ölçülü olmayan her türlü sınırlama hukuka aykırı sayılmalıdır. Bu yönde bir düzenlemeye Türk Medeni Kanunu'nda yer verilmesi, elbette kişilik haklarının ilgili kişinin kurumda bulunduğu süreçte daha etkin bir şekilde korunmasını sağlayacaktır. $\mathrm{Bu}$ şekilde kişi hürriyeti kapsamında yer alan hareket özgürlüğünün kısıtlanması, AİHS m 5/I ve AY m 19/II hükümlerinin emrettiği şekilde, hukuki bir dayanağa da kavuşturulmuş olacaktır. Kanaatimizce TMK m 432 hükmü, kişinin kurum içindeki hareket özgürlüğünün kısıtlanması bakımından başlı başına hukuki dayanak olarak ele alınamaz.

Kişi özgürlüğünün koruma amacıyla kısıtlandığı hallerde amaç, kişinin ihtiyaç duyduğu kişisel korumanın sağlanmasıdır. İhtiyaç duyulan kişisel koruma, özgürlüğü kısıtlanan kişinin tedavi edilmesini de gerektirebilir. Bu ihtimalde koruma amacıyla özgürlügün kısıtlanmasına ilişkin olarak verilen kararın, kişinin iradesi hilafına gerçekleştirilecek olan tedaviler bakımından hukuki bir dayanak sağlayıp sağlamadığının tartışılması gerekir. Bir diğer ifadeyle, ihtiyaç duyduğu kişisel koruma sebebiyle özgürlüğü kısıtlanan kişi, zorla tedavi edilebilecek midir? Türk Medeni Kanunu m 432 vd hükümlerinin zorla tedavi bakımından hukuki dayanak teşkil edip etmediği hususunda bir sonuca varılabilmesi bakımından, öncelikle hukuk sistemimizin zorla tedaviye hangi hallerde ve hangi şartlarla izin verdiğinin incelenmesi gerekmektedir.

\section{a. Kanun hükmü ile zorla tedavi imkanı getirilebilmesinin șartları}

Tıbbi müdahale, kişilik hakkı kapsamında korunan değerlere etki etmesi dolayısıyla hukuki dayanağa sahip olmadığı müddetçe kişilik hakkını ihlal eden, hukuka aykırı bir fiil olarak nitelendirilmelidir ${ }^{126}$. Hukuk düzeninin öngörmüş olduğu kurallar çerçevesinde gerçekleşen bir tıbbi müdahalenin hukuka uygun sayılabilmesi için, ilgilinin rızasına dayanıyor olması gerekir.

Kişinin maddi ve manevi bütünlüğü, AY m 17 hükmü ile koruma altına alınmıştır. "Kişinin dokunulmazlığı, maddî ve manevî varlığı" başlıklı hükmün ilk fikrası uyarınca: "Herkes, yaşama, maddî ve manevî varliğını koruma ve geliştirme hakkına

\footnotetext{
26 Thomas Geiser, 'Die medizinisch-therapeutische Behandlung und Zwangsmassnahmen im Lichte der geltenden Rechtslage und besonderer Berücksichtigung von vormundschaftlichen Fragestellungen' (2001) Zeitschrift für Vormundschaftswesen 234 .
} 
sahiptir”. Söz konusu hükmün ikinci fikrası ise, kişinin vücut bütünlügünü konu edinmiştir. Buna göre; "Tıbbî zorunluluklar ve kanunda yazılı haller dışında, kişinin vücut bütünlüğüne dokunulamaz; rızası olmadan bilimsel ve tıbb̂̀ deneylere tâbi tutulamaz”. Tıbbi müdahale, kişinin maddi ve manevi bütünlüğünün yanı sıra AY m 19 hükmü ile korunan kişi hürriyetine de etki etmektedir. Hukuk düzeni tarafindan korunan temel hak ve hürriyetlere etki eden tıbbi müdahalenin hukuka uygun olmas1, ilgili kişinin bu tıbbi müdahaleye geçerli şekilde rıza vermiş olmasına bağlıdır ${ }^{127}$. Rıza ile yapılan tıbbi müdahalenin hukuka uygun sayılabilmesi için, öncelikle tıbbi müdahaleye verilen rıza geçerli olmal1 ${ }^{128}$ ve tıbbi müdahale hukuk düzeni tarafından tıbbi müdahaleler için öngörülen hükümlere uygun olmalıdır. Türk Hukuku bakımından, 11 Nisan 1928 tarihli ve 1219 sayılı Tababet ve Şuabatı San'atlarının Tarzı İcrasına Dair Kanun ile 01.08.1998 tarihli ve 23420 sayılı Resmî Gazete’de yayınlanmış olan Hasta Hakları Yönetmeliği, bu hususta önem arz eder.

127 Ayrıntılı bilgi için bkz Gülay Arslan-Öncü, Avrupa İnsan Hakları Sözleşmesi’nde Özel Yaşamın Korunması Hakkı (Beta 2011) 87; Ayrica bkz Y.F. v. Turkey, (App. No:24209/94) Judgment of the ECHR of 22 July 2003, para 12, (Söz konusu kararın Türkçe çevirisi için bkz Gülay Arslan, 'Avrupa İnsan Hakları Mahkemesinin Özel Yaşam Hakkına Müdahaleyle Elde Edilmiş Deliller Hakkındaki Güncel Kararlarının İlgili Paragrafları’ iç Yener Ünver (edt) Karşılaştırmalı Güncel Ceza Hukuku Serisi, Özel Yaşam (VII) Medya ve Ceza Hukuku (Seçkin 2007) 465-475.

1281219 Sayılı ve 11.04.1928 tarihli Tababet ve Şuabatı San'atlarının Tarzı İcrasına Dair Kanun, tıbbi müdahale bakımından rızayı m 70 hükmünde düzenlemektedir. 01.08.1998 tarihli ve 23420 sayılı Resmî Gazete'de yayınlanarak yürürlüğe giren Hasta Hakları Yönetmeliği uyarınca da genel kural, tıbbi müdahalenin rızaya dayanmasıdır. İlgili Yönetmeliğin $\mathrm{m}$ 22/I hükmüne göre: "Kanunda gösterilen istisnalar hariç olmak üzere, kimse, rızası olmaksızın ve verdiği rızaya uygun olmayan bir şekilde tıbbi ameliyeye tabi tutulamaz". Hükmün ikinci fıkrası uyarınca: "Bir suç işlediği veya buna iştirak ettiğ $\breve{i}$ şüphesi altında bulunan kişinin işlediğ $i$ suçun muhtemel delillerinin, kendisinin veya mağdurun vücudunda olduğu düşünülen hallerde; bu delillerin ortaya çıkarılması için sanığın veya mağdurun tıbbi ameliyeye tabi tutulması, hâkimin kararına bağlıdır". Hükmün son fikrasında ise, gecikmesinde sakınca bulunan hallerde tıbbi müdahale, cumhuriyet savcısının talebi üzerine yapılabilecektir. Söz konusu Yönetmeliğin m 24 hükmü ise tıbbi müdahalelerde hastanın rızasının aranması gerektiğini açıkça ifade etmiştir. Buna göre hastanın küçük veya kısıtlı olması durumunda, velisinden veya vasisinden izin alınır. Bununla birlikte, hastanın velisinin ya da vasisinin olmadığı veya hazır bulunamadığı veya hastanın ifade gücünün olmadığı hallerde, rıza şartının aranmayacă̆ı ifade edilmiştir. Kanaatimizce hastanın rızasının aranmadığı bu son hal, acil durumlar ile sınırlı olmalıdır. Aynı yönde İmamoğlu 'Zorla Tedavi' (n 17) 36. Kanun koyucu, ilgili hükmün ikinci fikrasında, kanuni temsilcinin rızasının yeterli olduğu hallerde dahi, anlatılanları anlayabilecekleri ölçüde, küçük veya kısıtlı olan hastanın dinlenmesi suretiyle, mümkün olduğu kadar bilgilendirme sürecine ve tedavisi ile ilgili alınacak kararlara katılımının sağlanmasını öngörmüştür. Hükmün devamında, sağlık kurum ve kuruluşları tarafından engellilerin durumuna uygun bilgilendirme yapılmasına ve rıza alınmasına yönelik gerekli tedbirlerin alınması gereği düzenlenmiş̧ir. Kanuni temsilci tarafından rıza verilmeyen hallerde, müdahalede bulunmak tıbben gerekliyse velayet ve vesayet altındaki hastaya tıbbi müdahalede bulunulabilmesinin TMK m 346 ve 487 hükümleri uyarınca verilecek mahkeme kararına bağlı olduğu da yine m 24 hükmünün dördüncü fikrasında öngörülmüştür. Hükmün beşinci fikrasında ise tıbbi müdahale sırasında isteğini açıklayabilecek durumda bulunmayan bir hastanın, tıbbî müdahale ile ilgili olarak önceden açıklamış olduğu isteklerinin dikkate alınması gereği emredilmiştir. Bununla birlikte hastanın rızasının alınamadığı, hayati tehlikesinin bulunduğu ve bilincinin kapalı olduğu acil durumlar ile hastanın bir organının kaybına veya fonksiyonunu ifa edemez hale gelmesine yol açacak durumun varlığı halinde, hastaya tıbbi müdahalede bulunulması rızaya bağlı değildir. Ancak söz konusu halde, mümkünse hastanın orada bulunan yakını veya kanuni temsilcisinin, mümkün olmadığı takdirde de tıbbi müdahale sonrasında hastanın yakını veya kanuni temsilcisinin bilgilendirilmesi öngörülmüştür. Hastanın bilincinin açılmasının akabinde gerçekleştirilecek tıbbi müdahaleler, hastanın yeterliği ve ifade edebilme gücüne bağlı olarak rızası var ise gerçekleştirilebilecektir. Söz konusu düzenlemeler hakkında değerlendirme için bkz Oktay-Özdemir (n 22) $240 \mathrm{vd}$; Hasta Hakları Yönetmeliği m 25 hükmü ise hastanın tedaviyi reddetmek veya durdurulmasını istemek hakları ile ilgilidir. Buna göre, kanunen zorunlu olan haller dışında hasta, doğabilecek olumsuz sonuçların sorumluluğu kendisine ait olmak üzere, önerilen tedaviyi reddetme veya durdurulmasını isteme hakkına sahiptir. Söz konusu halde, tedavinin uygulanmamasından doğacak sonuçların hastaya veya kanuni temsilcilerine veyahut yakınlarına anlatılması ve bunu gösteren yazılı belge alınması gereği düzenlenmiștir. Hastanın tedaviyi reddetme veya durdurma hakkını kullanmasının, hastanın sağlık kuruluşuna tekrar müracaatında kendi aleyhine kullanılamayacağı da öngörülmüştür. Hasta Hakları Yönetmeliği'nin m 32/I hükmünde ise rıza, tıbbi araştırmalar bakımından düzenlenmektedir. Buna göre; "Hiç kimse; Bakanlı̆̆ın izni ve kendi rızası bulunmaksızın, tecrübe, araştırma veya eğitim amaçlı hiçbir tıbbi müdahale konusu yapılamaz". 
İlgilinin rızasına dayanmayan tıbbi müdahaleler, Avrupa İnsan Hakları Mahkemesi nezdinde, AİHS m 8 hükmünün ihlali olarak değerlendirilmiştir ${ }^{129}$. Tibbi müdahale ve özellikle de ilgilinin rızası hususlarında ele alınması gereken bir diğer uluslararası sözleşme, Avrupa Konseyi İnsan Hakları ve Biyotıp Sözleşmesi'dir ${ }^{130}$. Avrupa İnsan Hakları Mahkemesi'nin tıbbi müdahalenin hukuka uygunluğu aşamasında aradığ 1 koşullar, İnsan Hakları ve Biyotıp Sözleşmesi’nde düzenlenmiş olankoşullar ileözdeştir. Türkiye tarafindan 3 Aralık 2003 tarihinde kabul edilmiş olan ilgili Sözleşme'nin m 5 hükmünde, sağlık alanında herhangi bir müdahalenin, ilgili kişinin bu müdahaleye özgürce ve bilgilendirilmiş bir şekilde muvafakat etmesi ile yapılabileceği ifade edilmiştir. Hükmün ikinci fikrası uyarınca, ilgili kişinin, müdahalenin amacı, niteliği, sonuçları ve tehlikeleri hakkında önceden bilgilendirilmesi gerekmektedir. Üçüncü fikrada ise bu muvafakatin her zaman serbestçe geri alınabileceği düzenlenmiştir. Avrupa Konseyi İnsan Hakları ve Biyotıp Sözleşmesi'nin m 6 hükmü, muvafakat verme yeteneği bulunmayan kişilerin korunması ile ilgilidir. Hükmün ilk fikrası uyarınca, üzerinde yapılacak bilimsel araştırmaya muvafakat etme yeteneği bulunmayan kişilerin korunmasına dair m 17 hükmü ve organ alınmasına muvafakat verme yeteneği olmayan kişilerin korunmasına dair m 20 hükmüne tabi olmak koşuluyla, muvafakat verme yeteneği bulunmayan bir kimse üzerindeki tıbbi müdahale, sadece kendisinin doğrudan yararı için yapılabilir. Hükmün ikinci fikrası uyarınca; "Kanuna göre bir müdahaleye muvafakatini verme yeteneği bulunmayan bir küçüğe, sadece temsilcisinin veya kanun tarafindan belirlenen makam, kişi veya kuruluşun izni ile müdahalede bulunulabilir". Hükmün üçüncü fikras1 uyarınca ise: "Kanuna göre, akll hastalığl, bir hastallk veya benzer nedenlerden dolayl, müdahaleye muvafakat etme yeteneği bulunmayan bir yetişkine, ancak temsilcisinin veya kanun tarafindan belirlenen kişi veya makamın izni ile müdahalede bulunulabilir”.

Bu halde kişinin rızası alınmaksızın yapılan tıbbi müdahalaler, kural olarak hukuka aykırıdır. Bununla birlikte İnsan Hakları ve Biyotıp Sözleşmesi m 8 hükmü, acil bir durum nedeniyle uygun bir rızanın verilemediği hallerde, ilgili bireyin sağlığ 1 için gerekli olan herhangi bir tıbbi müdahalenin yapılabileceğini öngörmüştür. Nitekim Hasta Hakları Yönetmeliği m 24 hükmünün yedinci fikrası da acil durumlarda rızanın aranmamasını düzenlemiştir.

129 Arslan-Öncü (n 127) 91. Ayrıca bkz Tirado Ortiz and Lozano Martin v. Spain, (App. No. 43486/98), Admissibility Decision of the ECHR of 15 July 1999, paragraph 2, (http://hudoc.echr.coe.int/app/conversion/pdf/?library=ECHR\&id=0015635\&filename $=001-5635$.pdf\&TID=ihgdqbxnfi Erişim Tarihi 28 Mayıs 2020).

130 İnsan Hakları ve Biyotıp Sözleşmesi ile Avrupa İnsan Hakları Sözleşmesi arasında sıkı bir bağ bulunmaktadır. İnsan Hakları ve Biyotıp Sözleşmesi’nde, “insan hakları” ibaresi ile Avrupa İnsan Hakları Sözleşmesi’ne gönderme yapıldığı ifade edilerek, İnsan Hakları ve Biyotıp Sözleşmesi’nin Avrupa İnsan Hakları Sözleşmesi’ndeki bir takım prensiplerin geliştirilmesine hizmet ettiği ifade edilmektedir. Konu hakkında bkz Arslan Öncü, s. 89, 34 numaralı dipnot. Ayrıca bkz İnsan Hakları ve Biyotıp Sözleşmesi Açıklayıcı Raporu, No: 164, m 9 (Explanatory Report to the Convention for the protection of Human Rights and Dignity of the Human Being with regard to the Application of Biology and Medicine: Convention on Human Rights and Biomedicine), ilgili rapor için bkz https://rmcoe.int/16800ccde5 Erişim Tarihi 28 Mayıs.2020). Avrupa İnsan Hakları Mahkemesi'nin İnsan Hakları ve Biyotıp Sözleşmesi'ne atıf yapmış olduğu bir karar için bkz Glass v. United Kingdom (App. No. 61827/00), Judgment of the ECHR of 9 March 2004, para. 75, , (http:// hudoc.echr.coe.int/sites/eng-press/pages/search.aspx?i=003-945840-974305 Erişim Tarihi 28 Mayıs 2020). İnsan Hakları ve Biyotıp Sözleşmesi'ne atıf yapılmış olan diğer AİHM kararları için bkz Arslan Öncü, s. 90, 35 numaralı dipnot. 
Bir kişinin kendi iradesi hilafına veya tedavi olma yönünde geçerli bir iradesi olmaksızın tedavi edilmesi, zorla tedavi olarak isimlendirilmektedir ${ }^{131}$. Zorla tedavi, kişinin maddi ve manevi bütünlüğünün yanı sıra kendi kaderini belirleme hakkına da müdahale teşkil etmektedir. O halde zorla tedavinin mümkün olup olmadığı, tıbbi müdahaleden etkilenen temel hak ve özgürlüklerin korunmasıyla ilgilidir.

Kişinin dokulmazlığı ile maddi ve manevi varlığını koruma altına alan AY m 17 hükmünün ikinci fikrası, tıbbî zorunluluklar ve kanunda yazılı haller dışında, kişinin vücut bütünlüğüne dokunulamayacağını, rızası olmadan bilimsel ve tıbbî deneylere tâbi tutulamayacağını düzenlemiştir. Kanun koyucu, AY m 19/II hükmüyle, toplum için tehlike teşkil eden bir akıl hastası, uyuşturucu madde veya alkol tutkunu, serseri veya hastalık yayabilecek bir kişinin bir müessesede tedavi, eğitim veya sslahı için kanunda belirtilen esaslara uygun olarak alınan tedbirin yerine getirilmesi amacıyla hürriyetinin kısıtlanabileceğginden söz etmiştir. Görüldüğü üzere, AY m 19/II hükmü kişi hürriyetinin sınırlanmasını, bu sınırlamanın şekil ve şartlarını düzenleyen bir kanun hükmünün bulunması şartı ile mümkün kılmıştır ${ }^{132}$.

Zorla tedavi, taraf olduğumuz anlaşmalar kapsamında da ayrıca incelenmelidir. Avrupa İnsan Hakları Mahkemesi, tıbbi müdahaleyi reddetme hakkını AİHS m 3 ve m 8 kapsamında inceleme konusu yapmaktadır ${ }^{133}$. Avrupa İnsan Hakları Sözleşmesi m 3 hükmünde hiç kimsenin işkenceye veya insanlık dışı ya da aşağılayıcı muameleye veya cezaya tabi tutulamayacağı ifade edilmiştir. Avrupa İnsan Hakları Sözleşmesi m 8/I hükmü uyarınca: "Herkes özel ve aile hayatına, konutuna ve yazışmasına saygı gösterilmesi hakkına sahiptir”. Hükmün ikinci fikrası uyarınca: "Bu hakkın kullanılmasına bir kamu makamının müdahalesi,ccc ancak müdahalenin yasayla öngörülmüş ve demokratik bir toplumda ulusal güvenlik, kamu güvenliği, ülkenin ekonomik refahı, düzenin korunması, suç işlenmesinin önlenmesi, sağlı̆̆ın veya ahlakın veya başkalarının hak ve özgürlüklerinin korunması için gerekli bir tedbir olması durumunda söz konusu olabilir".

O halde zorla tedaviden söz edebilmek, ancak bu yönde bir kanun hükmünün varlığg1 ile mümkündür. Öğretide, TMK m 24/II hükmünde ifadesini bulan "üstün nitelikte özel veya kamusal yarar" kavramlarının zorla tedavi bakımından hukuki dayanak teşkil edebileceği ileri sürülmektedir ${ }^{134}$. Ancak söz konusu kavramlar, zorla tedaviyi öngören yasal bir dayanak olarak nitelendirilmeye kesinlikle elverişli değildir. Zorla tedavi öngören hüküm, zorla tedavinin hangi şartlarda ve hangi usulde gerçekleşmesi

\footnotetext{
131 Geiser (n 126) 225; İmamoğlu 'Zorla Tedavi' (n 17) 31.

132 İmamoğlu ‘Zorla Tedavi' (n 17) 39 vd.

133 Konu hakkında ayrıntılı bilgi için bkz Arslan-Öncü (n 127) 86.

134 Gümüş (n 21) 205; Aydın Özdemir (n 64) 192: Yazar, özgürlüğü kısıtlanan kişinin TMK m 24 hükmü kapsamında sayılan hukuka uygunluk sebeplerinden daha üstün nitelikte özel yarar ve kamusal yarar kavramları kapsamında rızası olmaksızın tedavi edilebileceği görüşündedir.
} 
gerektiğini açıkça düzenlemiş olmalıdır ${ }^{135}$. Tıbbi müdahalenin kişilik hakkı kapsamında bulunan değerlere olan etkisi, zorla tedavi öngören hüküm karşısında kişilik hakkının korunmasının teminat altına alınmış olmasını gerektirir. Zorla tedavi öngören hüküm, öngördüğü şartlar ve usul itibariyle her halde ölçülülük ilkesine uygun olmalıdır ${ }^{136}$. Bu hüküm kapsamında yapılacak olan tıbbi müdahale, konu, yer, zaman ve kişi açısından amaca uygun şekilde sınırlandırılmalıdır ${ }^{137}$. Koruma amacıyla özgürlüğün kısıtlanması kurumunun vesayet tedbiri olması dolayısıyla, bu kurum kapsamında düzenlenmiş olan ve zorla tedaviye olanak sağlayan bir hüküm, tedaviyi ancak korunması hedeflenen kişinin menfaatine olarak öngörebilir. Yoksa kişi, bu kurum kapsamında toplumun veya üçüncü kişinin menfaatine yapılacak bir tedaviye zorlanamaz ${ }^{138}$.

Avrupa Konseyi İnsan Hakları Biyotıp Sözleşmesi, zorla tedavinin hangi hallerde getirilebileceğine dair sınırlayıcı düzenlemeler içermektedir. İlgili Sözleşme'nin $\mathrm{m} 7$ hükmünde, ayrıca akıl hastalığı olan kişilerin korunması amacıyla da bir düzenleme getirilmiştir. Buna göre; "Gözetim, denetim ve başka bir makama başvurma süreçleri dahil, kanun tarafindan öngörülen koruyucu şartlarla bağll olmak üzere, ciddi nitelikte bir akıl hastalı̆̆ı olan kişi, yalnızca böyle bir tedavi yapılmadiğı takdirde sağllğına ciddi bir zarar gelmesinin muhtemel olduğu durumlarda, muvafakati olmaksızın, akıl hastalığının tedavi edilmesini amaçlayan bir müdahaleye tabi tutulabilir". İnsan Hakları ve Biyotıp Sözleşmesi m 7 hükmünde "ciddi nitelikte akıl hastası" ifadesi kullanılmıştır. Buna göre kimlerin bu kapsamda olacağının tayini yönündeki yetki, iç hukuktadır ${ }^{139}$. Bu hususun iç hukukta düzenlenmesi aşamasında kişisel özgürlüğün korunmasına mümkün olan en fazla özenin gösterilmesi ve ilgili kişilerin en yüksek menfaatleri gerektirdiği ölçüde zorla tedavi yoluna başvurulması gerektiği belirtilmiştir ${ }^{140}$.

$\mathrm{Bu}$ durumda kanun koyucunun buraya kadar açıklanmış olan şartları ihtiva eden bir düzenleme ile zorla tedavi imkânını getirmesi, yalnızca akıl hastalığı dolayısıyla tedaviye rıza gösteremeyecek kişiler bakımından mümkündür. Avrupa İnsan Hakları Sözleşmesi ile İnsan Hakları ve Biyotıp Sözleşmesi, söz konusu sözleşmeye dair açıklayıcı rapor ile birlikte incelendiğinde, zorla tedavinin kural olarak tedaviye muhtaç olan kişinin korunması amacıyla mümkün kılındığı anlaşılmaktadır.

Bununla birlikte İnsan Hakları ve Biyotıp Sözleşmesi'nin m 26 hükmü, Sözleşme konusu hakların kısıtlanmasını düzenlemektedir. Hükmün ilk fikrası uyarınca; "Bu

\footnotetext{
135 Geiser (n 126) 235, 240; İmamoğlu 'Zorla Tedavi' (n 17) 54.

136 Geiser (n 126) 235.

137 İmamoğlu 'Zorla Tedavi' (n 17) 39.

138 Geiser (n 126) 225, 235.

139 Arslan-Öncü (n 127) 99.

140 İnsan Hakları ve Biyotıp Sözleşmesi Açıklayıcı Raporu (No: 164), paragraph 42, (ilgili Rapor için bkz https://rmcoe. int/16800ccde5, 19 Mayis 2020)
} 
Sözleşmede yer alan haklar koruyucu hükümlerin kullanılmasında, kamu güvenliği, suçun önlenmesi, kamu sağllğının korunması veya başkalarının hak ve özgürlüklerinin korunması için kanun tarafindan öngörülen ve demokratik bir toplumda gerekli olanlardan başka kisitlama konulmayacaktır".

Salgın hastalıkların tedavisi, kamu sağlığı ve başkalarının hak ve özgürlükleri ile yakından ilgilidir. Bu sebeplerle kamu sağlı̆̆ını tehdit edecek nitelikte olan hastalıklar ile, başkalarının hak ve özgürlüklerinin korunması bakımından gerekli olduğu hallerde, sözleşme tarafı devletlerin zorla tedaviye ilişkin yasal bir düzenleme getirmeleri, ölçülülük ilkesine de uygun olduğu müddetçe mümkündür. Sözleşme'nin m 26 hükmünün ikinci fikrasında bir takım hakların kısıtlanamayacağı ifade edilmekle birlikte, tedavinin, hastanın özgürce ve bilgilendirmiş bir şekilde muvafakat etmesi ile mümkün olabileceğine dair genel kural, söz konusu ikinci fikra hükmü kapsamına alınmamıştır.

Ağır tehlike arz eden salgın hastalıkların tedavisi başta kamu sağlığı olmak üzere, kamu düzeni ile yakından ilgilidir. Bu halde kişinin tedavisi, yalnızca hasta olan kişinin kendisinin korunması ile ilgili olmadığından, ağır tehlike arz eden salgın hastalığın zorla tedavisinin vesayet hükümleri kapsamında düzenlenmesi mümkün değildir. Nitekim Türk Hukuku'nda 24 Nisan 1930 tarihinde kabul edilmiş olan 1593 sayılı Umumi Hıfzıssıhha Kanunu yürürlükte olup, ağır tehlike arz eden hastalıklar

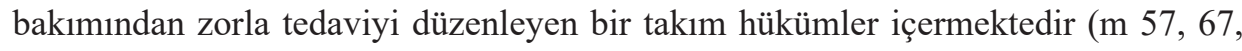
72, 88, 101, 107 ve 119 hükümleri). Türk Hukuku'nda kamu sağlığının korunması amacı dışında zorla tedaviyi öngören ceza hukuku kuralları da bulunmaktadır ${ }^{141}$.

\section{b. Koruma Amacıyla Özgürlüğün Kısıtlanması Kurumunun Zorla Tedavinin Hukuki Dayanağını Teşkil Edip Etmediği}

Koruma amacıyla özgürlüğün kısıtlanması kurumunu ilk defa düzenlemiş olan 4721 sayılı Türk Medeni Kanunu'nun gerekçesinde, söz konusu kurumun zorla tedaviye imkân tanıyıp tanımadığı hakkında açıklayıcı bir ifade yer almamaktadır. Öğretide tıbbi tedaviler bakımından bir ayrım yapılmaktadır. Kişinin kuruma yerleştirilebilmesi için zorunlu olan tıbbi müdahalelerin TMK m 432 uyarınca verilmiş olan karar gereği zorla yapılması mümkündür. Buna göre, ilgiliye, yerleștirildiği kurumda geçici olarak sakinleşmesi için zorla ilaç verilebilecektir ${ }^{142}$. Kişiye bu şekilde sakinleştirici ilacın rızası hilafına verilmesi, kuruma yerleştirme tedbirinin gereği olarak görülmekte ve bağımsız bir tedavi olarak nitelendirilmemektedir. Bununla birlikte söz konusu müdahalelerde de ölçülülük ilkesine uygun davranılması gereği unutulmamalıdır. Ölçülülük ilkesi, yalnızca kişinin özgürlüğünün kısıtlanıp

\footnotetext{
141 Bu anlamda TCK. m 57 ile Ceza ve Güvenlik Tedbirlerinin İnfazı Hakkında Kanun m 82 hükmü örnek gösterilebilir. İmamoğlu 'Zorla Tedavi' (n 17) 39, dpn. 65 ve 66.

142 Gümüş (n 21) 205; İmamoğlu 'Zorla Tedavi' (n 17) 52.
} 
k1sıtlanmayacağı noktasında değil, kişinin hak ve özgürlüklerine kurum içerisinde yapılacak olan her türlü müdahale bakımından geçerlidir.

Kuruma yerleştirilen veya kurumda alıkonulan kişinin sağlığı yönünden tehlike yaratan acil hallerde, gerekli tedavinin ayrıca rıza aranmaksızın yapılması, Biyotıp Sözleşmesi m 8 hükmüne uygun şekilde, Hasta Hakları Yönetmeliği m 24/III hükümleri kapsamında mümkündür ${ }^{143}$.

Koruma amacıyla özgürlüğün kısıtlanmasına ilişkin TMK m 432 vd hükümleri, kişinin kuruma yerleştirilebilmesi veya burada alıkonulması hedeflerine ulaşılması dışında, zorla tedavi bakımından hukuki dayanak olarak ele alınmamaktadır ${ }^{144}$. Tıbbi tedavinin kişilik değerleri üzerindeki etkisi, TMK m 432 vd hükümlerinin her türlü kişisel koruma için getirilmiş son derece genel hükümler olduğu ve tıbbi tedaviler bakımından koruyucu özel hükümler içermediği hususu dikkate alındığında, söz konusu hükümlerin zorla tedavi bakımından dayanak olarak kabul edilmeleri hukuka uygun görünmemektedir. Bir hükmün zorla tedavi bakımından hukuki dayanak teşkil etmesi için, tedavinin şekil ve şartları bakımından ayrıntılı düzenlemeler içermesi gerekmektedir $^{145}$. Oysa TMK m 432 vd hükümlerinde bu yönde düzenlemelere yer verilmemiştir

Kaynak İsviçre Medeni Kanunu, koruma amacıyla özgürlüğün kısıtlanması kurumuna ilk defa 1978 yılında yer vermiştir. Koruma amacıyla özgürlügüun kısıtlanması kurumunun düzenlenmesi amacıyla sevk edilen hükümlerde açıça tedaviden söz edilmemiş olması sebebiyle, uygulamada ${ }^{146}$ ve öğretide ${ }^{147}$, ilgili hükümlerin zorla tedavi bakımından hukuki dayanak teşkil edemeyeceği ileri sürülmüştü. Ancak İsviçre Medeni Kanunu'nun vesayet hükümlerinde 19 Aralık 2008 yılında yapılan esaslı değişiklikle, ayırt etme gücü olmayan kişiler bakımından zorla tedavi imkânı getirilmiştir. Özgürlüğü kısıtlanan kişiye sağlanması gereken tıbbi tedavinin hangi prosedürlere ve şartlara uyularak gerçekleştirileceği ayrıntılı şekilde düzenlenmiştir ${ }^{148}$. "Psikolojik hastalıklarda alınacak tıbbi önlemler” başlı̆̆ altında, "Rızanın olmadığı hallerde tedavi” kenar başlığı ile düzenlenmiş olan İsviçre Medeni Kanunu m 434 hükmü, zorla tedavi için bir takım şartlar aramıştır. Bunlar; (1) tedavinin gerçekleşmemesi halinde hastalığın ilgilinin kendi sağlığını ciddi

\footnotetext{
${ }^{143}$ İsviçre Medeni Kanunu m 435 hükmü, psikolojik bir hastalığın söz konusu olması halinde, kişinin kendisini veya üçüncü kişileri ilgilendiren acil bir durum karşısında gerekli tedbirlerin derhal alınmasını öngörmüştür. Bu halde kişi, daha önce kuruma tedavisinin ne şekilde olması gerektiğine dair bir irade beyanında bulunmuşsa ilgili kurum, söz konusu kişinin bu beyanını da dikkate almalıdır

144 Dural, Öğüz ve Gümüş (n 31) N 2182; İmamoğlu 'Zorla Tedavi' (n 17) 54; Geiser (n 17) Vor Art 397a-f N 7; Geiser (n 126) 237; Ayrica bkz; BGE 118 II 254, s. 262; BGE 126 I 112, s. 115 vd; ; BGE 127 I 6, s. 8 vd, (www.bger.ch Erişim Tarihi 20 Mayis 2020).

145 İmamoğlu 'Zorla Tedavi' (n 17) 54

146 BGE 125 III 169; BGE 126 I 112 (kararlar için bkz www.bger.ch, Erişim Tarihi 20 Mayıs 2020).

147 Geiser (n 17) Art 397a N 4.

148 Konu hakkında ayrıntılı bilgi için bkz Tuor, Schnyder, Schmid and Jungo (n 18) § 57 N 28 vd; İmamoğlu 'Zorla Tedavi' (n 17) $48 \mathrm{vd}$.
} 
şekilde tehdit etmesi ya da üçüncü kişilerin vücut bütünlüğünü veya yaşamını ciddi nitelikte tehlikeye atması, (2) ilgilinin tedaviyi gerektiren sebepler dolayısıyla ayırt etme gücünden yoksun olması, (3) duruma elverişli ve kişinin özgürlüklerine daha az müdahalede bulunan bir tedbirin bulunmaması, olarak sayılabilir. Bu şartların varlığı halinde, ilgiliye, yerleştirildiği veya alıkonulduğu bölümdeki yetkili doktorun tedavi planındaki tıbbi tedbirlerin uygulanabileceği kabul edilmiştir ${ }^{149}$. Bu hali ile IMK. m 434 vd hükümlerinin Avrupa Konseyi İnsan Hakları ve Biyotıp Sözleşmesi m 7 hükmü ile uyum içerisinde olduğu ifade edilmelidir ${ }^{150}$.

Sonuç olarak, TMK m 432 hükmünün kişisel koruma sağlama işlevinin ifası için kişinin kuruma yerleştirilmesini öngören bir kanun hükmü olduğu ve bu anlamda özgürlüğü kısıtlanan kişinin zorla tedavi edilmesi için hukuki dayanak teşkil etmeyeceğinin kabulü gerekir. İfade etmek gerekir ki zorla tedavi, kişilik hakk1 kapsamında korunan değerlere olan yoğun etkisi itibariyle, son derece istisnai hallerde başvurulan bir çare olmalıdır. Kişinin tedaviye rızası ile başlamasının başarı şansını arttırdığı da dikkate alınarak, öğretide ayırt etme gücü olmayan kişilerin dahi, tedavi aşamasında karar alma sürecine mümkün olduğu kadar dâhil edilmesi gereği haklı olarak savunulmaktadır ${ }^{151}$. Nitekim İnsan Hakları ve Biyotıp Sözleşmesi de, ilgili kişinin menfaatine yönelik olarak oldukça dar bir alanda zorla tedaviyi mümkün görmüştür (m 7). Kişisel korumanın ancak tedavi ile gerçekleştirilebileceği hallerde, şayet özgürlüğü kısıtlanan kişi tedaviye rıza göstermezse, özgürlüğün kısıtlanması yönündeki tedbir çoğunlukla anlamsız kalacaktır ${ }^{152}$. Tedaviye rıza gösterme hususunda ayırt etme gücüne sahip olmayan kişilerin bu halde ömür boyu yerleştirildikleri kurumda alıkonulmaları gerekir ki, bu husus esasen TMK m 432 vd hükümlerinin amacı ile uyumlu değildir. İsviçre' de 2008 yılında yapılan kanun değişikliğine dair gerekçede, bir takım özel hallerde zorla tedavinin kabul

149 İsviçre Medeni Kanunu m 433/I uyarınca, yazılı tedavi planının hazırlanmasına hekimin yanı sıra tedavi görecek ilgilinin kendisi ile varsa güvendiği üçüncü bir kişi de katılabilecektir. Hekim, ilgiliyi ve varsa onun güvendiği üçüncü kişiyi, planlanan tedavi bakımından önem arz eden bütün konularda bilgilendirir. Bu kapsamda özellikle tedavinin sebepleri, amacı, şekli, yöntemi, riskleri ve yan etkileri, tedavinin yapılmamasının sonuçları ve alternatif tedavi yöntemleri hususunda bilgilendirme yapılır. Tedavi planı, ilgili kişinin onayına sunulur. Ayırt etme gücü olmayan kişinin varsa önceden açıklamış olduğu istekleri de bu aşamada dikkate alınır. Ancak ilgili kişi tedaviye rıza göstermezse bu halde, ancak İMK. m 434 hükmünün şartları varsa zorla tedavi söz konusu olabilir. Kanun koyucu, bu aşamada ilgilinin rızasının alınmaya çalışılmasının son derece önemli olduğunu, 19 Aralık 2008 tarihli Kanun'un gerekçesinde özellikle vurgulamıştır. İlgilinin rızasının özellikle tedavinin başarıya ulaşması bakımından önem taşıdığına dikkat çekilerek, zorla tedavi halinde dahi, tedavi süreci boyunca ilgilinin isteklerinin dikkate alınması gereğine işaret edilmiştir. Bkz BBI 2006 7068, (https://www. admin.ch/opc/de/federal-gazette/2006/7001.pdf Erişim Tarihi 12 Mayıs 2020). Ayırt etme gücü olmayan kişilerin bedensel hastalıklarının da İMK. m 426 hükmü kıyasen uygulanmak suretiyle zorla tedavi edilebileceği yönünde Tuor, Schnyder, Schmid and Jungo (n 18) § 57 N 9, Bu halde tıbbi müdahalelerde ayırt etme gücü olmayan kişinin temsiline ilişkin İMK. $m$ 377 vd hükümlerinin uygulanması gerektiği görüşünde Guillod (n 42) Art 426 N 56.

150 İsviçre kanun koyucusu, İMK. m 434 hükmünün, zorla tedavinin ilgilinin koruma amacıyla kuruma yerleştirilmesi hali ile sınırlı şekilde düzenlenmiş olması ve uygulama alanının ayırt etme gücü olmayan kişilerle sınırlandırılmış olması sebebiyle, İnsan Hakları ve Biyotıp Sözleşmesi m 7 hükmüne kıyasla daha dar bir uygulama alanına sahip olduğunu ifade etmiştir. BBI 2006 7069, (https://www.admin.ch/opc/de/federal-gazette/2006/7001.pdf Erişim Tarihi 18 Mayıs 2020). İsviçre kanun koyucusu, İMK. m 435 hükmünde ise acil hallerde gerçekleşmesi gereken tıbbi müdahaleleri düzenleyerek, İnsan Hakları ve Biyotıp Sözleşmesi m 8 hükmünün gereğini yerine getirmiştir. Bkz BBI 20067070.

151 İmamoğlu 'Zorla Tedavi' (n 17) 53.

152 Aynı yönde İmamoğlu 'Zorla Tedavi' (n 17) 53. 
edilmemesi durumunda, psikiyatri kliniklerinin de bu haldeki kişiler bakımından gözetim kurumlarına dönüşeceği ifade edilmiştir ${ }^{153}$. O sebeple temennimiz, Türk Hukuku'nda, İnsan Hakları ve Biyotıp Sözleşmesi m 7 hükmü ile çizilmiş olan yasal çerçevede, zorla tedaviye cevaz veren hükümlerin getirilmesidir.

Bununla birlikte bulaşıcı hastalıkların tedavisi başka bir boyutta ele alınmalıdır. Özellikle kişinin tedavi edilmediği müddetçe taşıdığı hastalığın bulaşma riskinin devam ettiği hallerde tedavi, vücut bütünlüğüne müdahale edilen kişinin yanı sıra toplumun diğer fertlerini de yakından ilgilendirmektedir. Bir diğer ifadeyle, salgın hastalıkların tedavisi bazı şartlarla kamu sağlığı ve dolayısıyla kamu düzeni ile yakından ilgilidir. Bu sebepledir ki İnsan Hakları ve Biyotıp Sözleşmesi m 26 hükmü, kamu sağlığının söz konusu olduğu hallerde, Sözleşme kapsamında korunan bir takım hakların sınırlandırılmasını mümkün görmüştür. Türk Hukuku'nda salgın hastalıkların önlenmesi 1593 sayılı Umumi Hifzıssihha Kanunu kapsamında düzenlenmektedir. İlgili Kanun, bir takım hallerde tecrit uygulamasının yanı sıra ayrıca zorla tedaviyi de düzenlemektedir. Söz konusu Kanunun ilgili hükümlerinin kısaca ele alınmasında fayda vardır.

\section{Umumi Hıfzıssıhha Kanunu'nda Zorla Tedaviye IIlişkin Hükümler}

Bir önceki başlıkta ele aldığımız üzere, MK m 432 vd hükümleri, zorla tedaviye hukuki dayanak teşkil etmemektedir. Ülkemizde 24 Nisan 1930 tarihinde kabul edilmiş olan 1593 sayılı Umumi Hıfzıssihha Kanunu yürürlüktedir. Söz konusu Kanun'un amacı, m 1 hükmünde ifade edildiği üzere, ülkenin sağlık şartlarını iyileştirmek ve milletin sağlığına zarar veren bütün hastalıklar veya diğer sağlığa zararlı etkenlerle mücadele etmek ve müstakbel neslin sağliklı olarak yetişmesini temin ve halka tıbbi ve toplumsal yardım sağlamaktır. İlgili hükümde tüm bu hususların Devlet hizmetlerinden olduğu ifade edilmiştir. İlgili Kanun, bulaşıcı hastalıklarla mücadele hususunda bir takım düzenlemeler içermektedir.

Söz konusu Kanun m 23 hükmü uyarınca, her vilayet merkezinde bir umumi hıfzıssıhha meclisi toplanır. Bu Meclis'in ayda bir defa toplanması hükme bağlanmıştır. Bununla birlikte olağanüstü bir durumda veya ciddi ve salgın hastalık halinde yetkililerin daveti ile daha sik toplanabilecekleri öngörülmüştür (m 26). Umumi hıfzıssıhha meclislerinin o yerin sağlık durumunu dikkate alarak, şehir, kasaba ve köylerde sağlık durumunun iyileştirilmesine ve mevcut tehlikelerin giderilmesine yarayan tedbirleri alabilecekleri düzenlenmiştir. Söz konusu meclisler, ciddi nitelikte salgın hastalık hakkında bilgi toplamak, hastalıktan korunmanın çareleri ve sağlıklı bir yaşamın faydaları hakkında halkı bilgilendirmekle yükümlü tutulmuşlardır. Ciddi nitelikte salgın hastalı̆̆ın giderilmesi için alınan tedbirlerin ifası

53 BBI 2006 7070, (https://www.admin.ch/opc/de/federal-gazette/2006/7001.pdf Erişim Tarihi 18 Mayıs 2020). 
bakımından yardımcı olmak da, yine söz konusu meclisin yükümlülükleri arasındadır (m 27). Bununla birlikte ağır tehlike arz eden bulaşıcı hastalığ1 taşıyan kimselerin tecrit edilmesi ve zorla tedavisi, AY m 19 hükmü ile teminat altına alınmış olan kişi hürriyeti ve kişi güvenliği ile ilgili olduğundan, meclislere bu hususta karar alma yetkisinin tanınmış olduğu kabul edilemez. Kişi hürriyetinin sınırlandırılmasının şartları kanun ile düzenlenmiş olmalıdır. Yoksa devletin bir organına yasal düzenlemeyle bir takım şartlar öngörülmeksizin, gerektiğinde bu hususta karar alma yetkisi verilemez. Nitekim Umumi Hifzıssıhha Kanunu'nda bir takım salgın hastalıkların varlığı halinde kişi hürriyetinin yetkili makamlarca sınırlanabileceğine ilişkin yasal düzenlemeler mevcut olup, söz konusu düzenlemelerle, kişi hürriyetinin sınırlandırılması hususunda yasallık şartının yerine getirilmesi hedeflenmiştir.

Umumi Hıfzıssıhha Kanunu m 49 hükmü bu yönde bir düzenlemedir. İlgili hüküm, Türkiye limanlarına ciddi ve salgın hastalığın girmemesi için Hudutlar ve Sahiller Umum Müdürlüğü tarafından alınabilecek olan tedbirleri düzenlemiştir. $\mathrm{Bu}$ tedbirlerden birisi de, bulaşıcı hastalık taşıdığından şüphe edilen yolcuların nezaret altında bulundurulması veya tecridi hususundadır (m 49/b 2). Söz konusu m 49 hükmünün üçüncü bendinde, hastaların tahaffuzhane ${ }^{154}$ veya salgın hastalıklar hastanelerinde şifa buluncaya kadar tedavi ve etrafları için tehlike arz etmeyinceye kadar tecrit edilebilecekleri öngörülmüştür (b. 3). Bir diğer tedbir ise yolcu ve mürettebata aşı yapılması veya serum verilmesidir (b. 6).

Umumi Hıfzıssıhha Kanunu m 49 hükmünde öngörülen tedbirler, m 37 hükmü uyarınca kolera, veba, sarıhümma, lekelihümma, çiçek hastalıkları ile Sağlık Bakanlığı'nca belirlenerek ilan edilecek olan diğer tehlikeli salgın hastalıklar söz konusu ise alınabilir. Kanun koyucu, m 49 hükmünde yer alan tedbirleri kara hudutları bakımından m 54 hükmünde, hava yolu ile ülkeye giriş yapacak olan kişi ve eşyalar bakımından ise $\mathrm{m} 56$ hükmünde düzenlemiştir.

Umumi Hıfzıssıhha Kanunu'nun "Memleket dahilinde sari ve salgin hastaliklarla mücadele" başlıklı ikinci fasılında yer alan m 57 hükmü uyarınca; "Kolera, veba (Bübon veya zatürree şekli), lekeli humma, karahumma (hummayi tiroidi) daimi surette basil çıkaran mikrop hamilleri dahi - paratifoit humması veya her nevi gıda maddeleri tesemmümatı, çiçek, difteri (Kuşpalazı) - bütün tevkiatı dahi sari beyin humması (Ilttihabı sahayai dimağii şevkii müstevli), uyku hastalığı (Iltihabı dimağii sari), dizanteri (Basilli ve amipli), lohusa hummass (Hummai nifası) ruam, kzzl, şarbon, felci tıfli (Illtihabı nuhai kuddamii sincabii haddı tifli), kızamık, cüzam (Miskin), hummai racia ve malta humması hastalıklarından biri zuhur eder veya bunların birinden şüphe edilir veyahut bu hastalıklardan vefiyat vuku bulur veya mevtin bu hastalkklardan biri sebebiyle

\footnotetext{
154 "Sefer sırasında, yolcu ve çalışanların arasında bulaşıcı hastalık görülen gemilerin karantina sürelerini geçirmeleri, gerekli sağlık önlemlerinin alınması ve hastaların iyileştirilmeleri için büyük limanlara yakın kıyılara kurulmuş sağlık kuruluşu", $<$ https://sozluk.gov.tr/< Erişim Tarihi 8 Mayıs 2020.
} 
husule geldiğinden şüphe olunursa aşağıdaki maddelerde zikredilen kimseler vak'ayı haber vermeğe mecburdurlar. Kudurmuş veya kuduz şüpheli bir hayvan tarafindan ısırlmaları, kuduza müptela hastaların veya kuduzdan ölenlerin ihbarl da mecburidir". Kanun koyucu, söz konusu Kanun ile bulaşıcı ve salgın hastalıklarla mücadeleye ilişkin $\mathrm{m} 57$ vd hükümleri bakımından bir takım hastalıkları açıkça saymıştır. Bununla birlikte ilgili m 57 hükmünde belirtilmeyen bir hastalık hakkında Kanun'un m 57 vd hükümleri uyarınca tedbir alınması ise Sağlık Bakanlığı'na bırakılmıştır. Buna göre, $m$ 57 hükmünde sayılmayan bir hastalı̆̆ın yayılması veya yayılma tehlikesinin bulunması halinde Sağlık Bakanlığı, söz konusu hastalığın ülkenin tamamında veya bir kısmında ihbarının mecbur olduğu hususunda karar verebilecektir. Sağlık Bakanlığı, bu halde m 57 vd hükümlerinde adı geçen tedbirlerin tamamının veya bir kısmının söz konusu hastalığa karşı uygulanmasına da karar verebilecektir (m 64).

Umumi Hıfzıssıhha Kanunu kapsamında alınabilecek temel hak ve özgürlükleri sınırlayıcı nitelikte olan tedbirlerden bir diğeri, salgın hastalık hakkında araştırma ve inceleme yapan doktorun, araştırmaları bakımından gerekli olması halinde, hastayı ve hasta ile birlikte yaşayan evin sakinlerini muayene etmeye, hastalığın belirtileri ile seyrine dair açıklama ve bilgi talep etmeye yetkili kılınmış olmasıdır (m 67). Doktorun bu yetkilerini kullanmasına karşı koyanların TCK m 195 hükmü uyarınca cezalandırılacağı hüküm altına alınmıştır (UHK m 284). Bunun yanı sıra m 72 hükmünde ise hasta olanların veya hasta olduğundan şüphe edilenlerin ve hastalığı yaydığı bilimsel raporlarla tespit edilenlerin bilimsel olarak gereken müddet boyunca ve sağlık görevlilerince, evlerinde ya da tıbbi ve bilimsel şartları haiz yerlerde tecrit ve müşahede altında bulundurulabilecekleri düzenlenmiştir (m 72/ (b) 1). Aynı hükmün ikinci bendinde ise hastalara veya hastalığa maruz bulunanlara serum ve aşı uygulaması yapılabileceği düzenlenmiştir. Nitekim yedinci bentte ise bulaşıcı ve salgın hastalıkların baş gösterdiği kamuya açık yerlerin tehlike sona erinceye kadar tahliye edilmesi ve bu yerlere girişin engellenmesi mümkün kılınmıştır.

Benzer yönde düzenlemelere trahom hastalığı bakımından m 99 vd hükümlerinde yer verilmiştir. $\mathrm{Bu}$ kapsamda $\mathrm{m} 101$ hükmünde, trahom mücadele mıntıkalarında teşkil edilecek heyetlerin bütün ahaliyi muayene ve tescile, trahoma hastalığına yakalandığı anlaşılan hastaları tedavi amacıyla ilgili kurumlara celbe yetkili oldukları düzenlenmiştir. Hastalığı taşıyan kişilere gereken tedavinin ilgili kurumlarda uygulanacağı öngörülmüştür.

Zührevi hastalıklar bakımından ise m 107 hükmünde zorla tedavi ve tecrit uygulamasına ilişkin düzenleme yer almaktadır. Hükümde gerektiğinde bir kimse üzerinde bu amaçlarla cebir kullanılmasının dahi mümkün olduğu düzenlenmiştir. Verem hastalığına yakalanan kimselerin tecrit edilmesi ve zorla tedavisi edilmesine ilişkin esaslar ise m 119 hükmünde yer almaktadır. 
Umumi Hıfzıssıha Kanunu, yukarıda incelediğimiz üzere, salgın hastalık taşıyan veya salgın hastalık taşıma şüphesi bulunan kimselerin tecrit edilmesi, müşahade altına alınması ve zorla tedavi edilmesi hususlarında bir takım düzenlemeler içermektedir. İlgili Kanun'da her ne kadar salgın hastalığı taşıyan kimselerin tecridi ve zorla tedavisi bir takım hastalıklar ismen sayılarak düzenlenmiş olsa da, m 64 hükmü dolayısıyla Kanun'un 57 ila 96 maddeleri arasında sayılmış olan tedbirler, Sağlık Bakanlığı tarafindan karar verilmesi şartıyla Umumi Hıfzıssıhha Kanunu'nda sayılmamış olan salgın hastalıklar bakımından da uygulanabilecektir. Bununla birlikte içinde bulunduğumuz 2020 yılında salgın halini alan ve pandemi ilan edilen Covid 19 hastalığı da göstermektedir ki virüslerin mutasyona uğramaları ve bir takım diğer biyolojik sebepler kapsamında her zaman yeni bir bulaşıcı hastalığın salgın hastalık halini alması mümkündür. Bu halde Kanun'da bir takım hastalıkların ismen sayılmak yerine, tüm bulaşıcı ve salgın hastalıklar bakımından geçerli olabilecek şekilde tedbirlerin düzenlenmesi, Kanun'un güncel gelişmeler karşısında kolayca uygulanabilir olmasını sağlayacaktır.

Ayrıca her ne kadar m 37 ve 64 hükümleriyle Sağlık Bakanlı̆̆ı'nın Umumi Hıfzıssıha Kanunu'ndaki tedbirlerin Kanun'da ismen sayılmamış olan hastalıklar hakkında uygulanması hususunda karar almasına imkân tanınmışsa da, bu yöndeki düzenleme tekniği, zorla tedavi bakımından yasallık şartının yerine gelmiş olup olmadığı konusundaki tartışmaları beraberinde getirecektir. O sebeple Kanun'da bir hastalığın hangi hallerde kamu sağlığı ve kamu düzenini tehdit edebilecek boyutta olabileceğine dair tıp ve biyoloji bilimleri vasıtasıyla denetlenebilecek bir takım somut şartlar getirilerek, tüm bu hallerde uygulanabilecek tedbirlerin düzenlemesi amaca daha uygun bir yöntem olurdu.

İlgili Kanun, tecrit dışında serum bağlama veya aşı yapılması da dâhil olmak üzere, salgın hastalığa yakalanacak olan kişilerin zorla tedavi edilebileceği düzenlenmiştir. Bunun yanı sira Kanun, zorla tedavi halinde uygulanması gereken usul ve esaslar bakımından da temel ilke ve prensipler belirlemeli ve ayrıca ölçülülük ilkesini güvence altına alan düzenlemeler içermelidir. Ne var ki bu yöndeki düzenlemeler Umumi Hifzıssıhha Kanunu'nda yer almamaktadır. Bu halde söz konusu Kanun hükümlerinin serum bağlama veya aşı uygulaması dışındaki tedaviler bakımından yasallık şartını hangi oranda yerine getirdiği hususu, ayrıca tartışılmalıdır. Bununla birlikte, her ne kadar söz konusu Kanun'da tedavide uyulması gereken esaslar ve usul hakkında düzenleme bulunmasa da, tedavinin hukuka uygun sayılması gereken şartlar bakımından ilgilinin rızası dışında diğer kurallara uyulması gerekmektedir. Aksi halde uygulanacak olan zorla tedavinin hukuka uygun olduğundan söz edilemez. Zorla tedavi kapsamında yapılacak olan müdahalenin hukuka uygun sayılabilmesi, tedavi amacına yönelen ve bu amacı yerine getirmeye elverişli olan bir müdahale olmasına bağlıdır. Tedavi ve koruma amacı olmayan veya bu amaca elverişli 
olduğu hususunda güvenilir çalışmalar bulunmayan yöntemlerin yanı sıra, tıp veya biyoloji biliminin gelişmesine hizmet eden deneysel nitelikteki çalışmalara yönelik müdahalelere zorla tedavi kapsamında cevaz verilmesi söz konusu değildir ${ }^{155}$. Zorla tedavi, Türk Hukuku'nda yürürlükte olan ilgili kurallara uygun, şekilde yapılmalıdır. Bu hususta 11 Nisan 1928 tarihli ve 1219 sayılı Tababet ve Şuabatı San'atlarının Tarzı İcrasına Dair Kanun ile 01.08.1998 tarihli ve 23420 sayılı Resmî Gazete' de yayınlanmış olan Hasta Hakları yönetmeliği önem arz eder.

\section{Koruma Amacıyla Özgürlüğün Kısıtlanması İçin Aranan Şartların Değerlendirilmesi}

Koruma amacıyla özgürlüğün kısıtlanması kurumunun şartları, çalışmamızın başında da ifade ettiğimiz üzere, "önleyici güvenlik tedbirleri” bakımından hukuki dayanak oluşturmayı hedefleyen AY m 19/II hükmünden bire bir alınmıştır. Kanun koyucu, AY m 19/II hükmünde olduğu gibi, TMK m 432 hükmünde de akıl hastalığ1, akıl zayıflığı, alkol ve uyuşturucu madde bağımlılığı, ağır tehlike arz eden bulaşıcı hastalık ve serserilik sebeplerinden yola çıkmıştır. Bununla birlikte TMK m 432 hükmü, bir vesayet tedbiri olması itibariyle kişinin korunması amacına yönelmiş olmalıdır. "Önleyici güvenlik tebirleri” ise ihtiyacı olan kişilere kişisel koruma sağlamak hususundan farklı bir amaca, toplum güvenliğinin ve toplum sağlığının korunmasına hizmet etmektedir. O halde TMK m 432 hükmünün şartları hakkında yapılacak olan değerlendirme, bu kurumun bir vesayet tedbiri olduğu dikkate alınarak yapilmalidir.

Kanun koyucu, öncelikle, akıl hastalığı ve zayıflığı ile alkol ve uyuşturucu madde bağımlılı̆̆ını özgürlüğün kısıtlanması sebepleri arasında saymıştır. Bu sebepler, TMK m 405 ve 406 hükümlerinde bir takım diğer şartlarla kısıtlama sebebi olarak da öngörülmüşlerdir. İsviçre Medeni Kanunu'nda 19 Aralık 2008 tarihli Kanun ile yapılan değişiklikler sonucunda kanun koyucu, İsviçre Medeni Kanunu'nun ilgili m 426 hükmünde, zayıflık halleri bakımından metnin lafzını sadeleştirmiştir. Bu kapsamda, akıl hastalığı, akıl zayıflığı ile alkol ve uyuşturucu madde bağımlılı̆̆1 sebepleri, zihinsel engel ve psikolojik rahatsızlıklar başlıkları altında toplanmıştır.

Türk Medeni Kanunu m 432 hükmünün kapsamı, serserilik hali bakımından da amaca uygun bir şekilde daraltılmalıdır. Kişinin insan onuruna yakışır bir yaşam sürmeye tek başına yetkin olmadığı hallerde, toplum için tehlike arz etmemesine rağmen, diğer şartların da varlığı halinde TMK m 432 hükmü tarafindan sağlanan korumadan faydalanabilmesi gerekir. Diğer taraftan, insan onuruna uygun olmayan şartlarda yaşamını sürdüren ve içinde bulunduğu şartları tek başına değiştirme kabiliyetinden yoksun bir kişi de, daimi bir ikametgahı olması itibariyle TMK m

\footnotetext{
Oğuzman/Seliçi /Oktay-Özdemir, N 585.
} 
432 hükmü vasıtasıyla sağlanacak korumadan mahrum kalmamalıdır ${ }^{156}$. Böyle bir sonuç, vesayet hukukunun amacı ile bağdaşmayacaktır. Bu itibarla Türk Medeni Kanunu'nun serserilik yerine İsviçre Medeni Kanunu m 426 hükmünde olduğu gibi, "ağır bakımsızlık" haline yer vermesi, daha isabetli olacaktır.

Kanun koyucunun TMK m 432 hükmü kapsamında koruma amacıyla özgürlüğün kısıtlanması için saymış olduğu hallerden bir diğeri ise "ağır tehlike arz eden bulaşıcı hastalık" halidir. Ağır tehlike arz eden bulaşıcı hastalık taşıyan kimsenin özgürlüğünün kısıtlanması da yine toplumun korunmasına yöneliktir. Ağır tehlike arz eden bulaşıcı hastalığa yakalanan bir kişinin özel bir koruma ihtiyacı içerisinde olması elbette mümkündür. Ancak kanun koyucu, madde hükmünde diğer başka bir hastalığa yer vermemiştir. Örneğin kanser olan bir kişinin kişisel korunmaya ihtiyaç duyması halinde TMK m 432 hükmünün kendisi bakımından uygulanması mümkün değildir ${ }^{157}$. Bu halde akla, ağır tehlike arz eden bulaşıcı hastalığın kişiyi her zaman diğer başka hastalıklardan daha fazla koruma gereksinimine muhtaç edip etmediği sorusu gelmektedir. Bu soruya olumlu yanıt vermek mümkün değildir. O halde kanun koyucunun ağır tehlike arz eden bulaşıcı hastalık halini TMK m 432 hükmünün kapsamına alması, hastalığın yayılmasını engellemeye, bir diğer ifadeyle toplumun korunması amacına yöneliktir ${ }^{158}$. Kanun koyucunun ağır tehlike arz eden bulaşıcı hastalık taşıyan bir kişinin özgürlügünün sınırlanmasını öngörmesi, haklı bir menfaate yönelik olup, bu şekilde kamu sağlığı başta olmak üzere, kamu düzeninin korunması hedeflenmektedir. Nitekim 2020 yılı içerisinde yaşamakta olduğumuz Covid 19 hastalığı pandemisi sırasında cereyan eden olaylar, bu yönde bir hükme gereksinim olduğunu da açıkça ortaya çıkarmıştır. Zira bu nitelikte bir hastalığın yayılması, yalnızca toplumun fertlerinin sağlığını değil, sağlık sistemi başta olmak üzere, eğitimden ekonomiye birçok alanı kötü etkileyerek, ülke genelindeki yaşam şartlarını çekilemeyecek derecede zor bir hale getirebilmektedir.

Ancak, ağır tehlike arz eden bulaşıcı bir hastalığın varlığı halinde toplumun geneli bakımından arzu edilen korumanın TMK m 432 vd hükümleri ile sağlanması mümkün görünmemektedir. İncelediğimiz üzere, TMK m 432 hükmü zorla tedavi bakımından yasal dayanak oluşturmamaktadır. Söz konusu hüküm, kişisel korumanın yalnızca tedavi hali ile giderilebilmesi durumunda dahi, zorla tedavinin hukuki dayanağını oluşturmaya elverişli değildir.

Ayrıca, bir kişinin madde hükmünde sayılan sebeplerle özgürlüğünün kısıtlanabilmesi için vesayet makamından karar alınması gerekmektedir. Bununla birlikte Covid 19 virüsü örneğindeki gibi, hastalığın hızla yayılabileceği hallerde,

\footnotetext{
156 Kişinin evini çöplerle doldurması halinin serserilik kapsamında ele alınmasının araştırılması gerektiği yönünde bir karar için bkz Yarg.18. HD., 14.6.2016 T., 2016/9524 K., 2016/9547 K, (www.lexpera.comtr Erişim Tarihi 15 Mayıs 2020).

157 Kocaağa (n 17) 41; Aksi yönde Gümüş (n 21) 203.

158 Öztan (n 7) 1355; Gümüş (n 21) 199 vd; Kocaağa (n 17) 36.
} 
her bir hasta bakımından vesayet makamının kararının beklenmesi, hastalığın o esnada birçok kişiye bulaşmasına yol açabilecektir. Bu halde kişinin hâkim kararı beklenmeksizin toplumdan izole bir şekilde yaşamasının sağlanmasında kamu menfaati vardır. Buraya kadar aktarılan sebeplerle, ağır tehlike arz eden bulaşıcı hastalı̆̆ın yayılmasının önlenmesinin bir vesayet tedbiri olan koruma amacıyla özgürlüğün kısıtlanması ile sağlanması mümkün değildir. Nitekim Türk Hukuku'nda bu amaçlarla sevk edilmiş olan, 24 Nisan 1930 tarihli ve 1593 sayılı Umumi Hifzıssıhha Kanunu yürürlüktedir. Söz konusu Kanun hükümlerinin ağır tehlike arz eden bulaşıc1 hastalık halinde kamu menfaatini korumaya ne denli uygun olduğu ve söz konusu Kanun karşısında kişilik hakkının yeterli koruma görüp görmediği, düşünülebilir. Ancak bu konu, çalışmamızın sınırlarını aştığından, ayrıca ele alınamamıştır.

Kanun koyucu, öngörmüş olduğu zayıflık halleri dolayısıyla ilgilinin kişisel korumaya ihtiyaç duyması dışında ayrıca "toplum için tehlike oluşturma" şartına da hükümde yer vermiştir. Türk Medeni Kanunu m 432 hükmünde özgürlüğün kısıtlanması için öngörülmüş olan "toplum için tehlike oluşturma şartı", bulaşıcı hastalık dışında hükümde sayılan diğer sebepler bakımından uygulanmaya elverişli değildir. Koruma amacıyla özgürlüğün kısıtlanması, "vesayet" kurumu altında düzenlenmiş olup, belirli sebeplerle koruma gereksinimi duyan kişilerin korunmasına hizmet etmektedir. İlgili TMK m 432 hükmünün ilk fikrasında "kişisel korumanın başka şekilde sağlanamaması", özgürlüğün kısıtlanması için aranan bir başka şarttır. Dolayısıyla madde hükmünden de, özgürlüğün kişisel koruma amacıyla kısıtlanabileceği açıkça anlaşılmaktadır. Bu halde 'toplum için tehlike oluşturma' şartı ile kişinin hükümde sayılan sebeplerle "kişisel korumaya ihtiyaç duyması" şartlarını aynı anda aramak, madde hükmünün uygulama alanını amaca aykırı bir şekilde daraltacaktır. Örneğin uyuşturucu madde bağımlısı olan bir kişi veya sürekli kendisine zarar veren akıl hastası bir kişi, kişisel korumaya ihtiyaç duysa da, şayet bu kişiler toplum için tehlike oluşturmuyor ise vesayet kurumunca sağlanan korumadan faydalanmaları mümkün olmayacaktır.

Kanaatimizce hâkim, somut bir olayda TMK m 432 hükmünün uygulanıp uygulanmayacağ 1 hususunu, ilgili hükmün içinde yer aldığı vesayet kurumunun amacından yola çıkarak belirlemelidir. Bu halde, toplumun korunması için kişilerin zorla kuruma yerleştirilmelerine veya kurumda alıkonulmalarına cevaz veren kanun koyucunun, bu imkâna, ilgilinin kendisinin korunmasının gerektiği hallerde evleviyetle imkân vermesi gerektiği, gözden uzak tutulmamalıdır. Nitekim Türk Medeni Kanunu, m 23 hükmü özelinde, kişilik hakkının korunmasını kişinin kendisine karşı da gerçekleştirmektedir.

Son olarak ifade etmek gerekir ki, gerçek kişileri bir takım zayıflık halleri dolayısıyla etkin bir şekilde korumaya yönelik sevkedilmiş olunan koruma amacıyla 
özgürlüğün korunması kurumu, amacına ulaşması bakımından mutlaka zorla tedavi imkânını da içermelidir. İnsan Hakları ve Biyotıp Sözleşmesi $m 7$ hükmüne uygun şekilde sevkedilecek olan ve zorla tedaviye olanak sağlayan hükümler, özellikle zihinsel engelli ve psikolojik hastalıktan muzdarip kimselerin kurum dışında insan onuruna uygun bir yaşam süremelerini mümkün k1labilecektir. Ancak zorla tedavi imkânının getirilmediği hallerde söz konusu zayıflık hali içerisinde olan kişiler, belki de bütün ömürlerini kurumda geçirmek zorunda kalacaklardır. Bu son ihtimalde ilgili kişilerin yeterince korunduklarından söz etmek mümkün olmayacaktır. Zira bir kimsenin ömür boyu kurumda kalması, zorla tedavi ile karşılaştırıldığında daha ağır bir müdahale olup, ölçülülük ilkesine aykırı bir sonuca yol açmaktadır.

Hakem Değerlendirmesi: Diş bağımsız.

Çıkar Çatışması: Yazar çıkar çatışması bildirmemiştir.

Finansal Destek: Yazar bu çalışma için finansal destek almadığını beyan etmiştir.

Peer-review: Externally peer-reviewed.

Conflict of Interest: The author has no conflict of interest to declare.

Grant Support: The author declared that this study has received no financial support. 


\section{Bibliyografya/Bibliography}

Akıntürk T ve Ateş D, Türk Medeni Hukuku, Aile Hukuku, C 2 (22. Bası, Beta 2020).

Arslan G, “Avrupa İnsan Hakları Mahkemesinin Özel Yaşam Hakkına Müdahaleyle Elde Edilmiş Deliller Hakkındaki Güncel Kararlarının İlgili Paragrafları” iç Yener Ünver (edt) Karşılaşstırmalı Güncel Ceza Hukuku Serisi, Özel Yaşam (VII) Medya ve Ceza Hukuku (Seçkin 2007) 465-475.

Arslan-Öncü G, Avrupa İnsan Hakları Sözleşmesi’nde Özel Yaşamın Korunması Hakkı (Beta 2011).

Aydın Özdemir E, '19.12.2008 Tarihli İsviçre Medeni Kanunu Değişikliği ile Karşılaştırmalı Olarak Türk Medeni Kanunu'nda Koruma Amaciyla Özgürlüğün Kısıtlanması Düzenlemesi’, (2013) XV (2) Dokuz Eylül Üniversitesi Hukuk Fakültesi Dergisi 171-208.

Çavuşoğlu Işıntan, P, 'Türk Hukukunda Yeni Bir Müessese: Koruma Amacıyla Kişi Özgürlüğünün Kısıtlanması (TMK m 432-437)', (2002) I (2) Galatasaray Üniversitesi Hukuk Fakültesi Dergisi 297-306.

Dağlı, M, Emsal İçtihatlarla Türk Medeni Hukukunda Koruma Amacıyla Özgürlügüun Kısıtlanması (Turhan 2011).

Dural M and Öğ̈̈z T, Türk Özel Hukuku-Cilt II-Kişiler Hukuku (19. Baskı, Filiz 2018).

Dural M, Ögüz T ve Gümüş A, Türk Özel Hukuku-Cilt III-Aile Hukuku (14. Bask1, Filiz 2019).

Elçin Grassinger G, Küçüğün Kişi Varlığının Korunması İçin Alınacak Tedbirler (On İki Levha 2009).

Geiser T, 'Art 397a-405a' in Heinrich Honsell, Nedim Peter Vogt and Thomas Geiser (eds) Basler Kommentar zum Schweizerischen Privatrecht, Zivilgesetzbuch I (3rd edn, Helbing \& Lichtenhahn 2002).

Geiser T, 'Die medizinisch-therapeutische Behandlung und Zwangsmassnahmen im Lichte der geltenden Rechtslage und besonderer Berücksichtigung von vormundschaftlichen Fragestellungen' (2001) Zeitschrift für Vormundschaftswesen 225-243.

Guillod O, 'Art. 426-439'in Andrea Büchler, Christoph Häfeli, Audrey Lauba, Martin Stettler (eds) FammKomm: Erwachsenenschutz (Stämpfli 2013).

Gümüş, MA, 'Kısıtlı veya Kısıtlı Olmayan Ergin Kişilerin Koruma Amaçlı Özgürlüğünün Kısıtlanması (TMK 432-437)', (2004) I (2) Yeditepe Üniversitesi Hukuk Fakültesi Dergisi 189-228.

Helvacı S, Gerçek Kişiler (8. Bası, Legal 2017).

İmamoğlu S H, 'Hukuki Açıdan, Özellikle Koruma Amacıyla Özgürlüğün Kısıtlanmasına İlişkin Hükümler Çerçevesinde Zorla Tedavi’ (2012) VII (3-4) Erciyes Üniversitesi Hukuk Fakültesi Dergisi 29-59 ('Zorla Tedavi').

İmamoğlu S H, 'İsviçre Medeni Kanununun Yurtlarda veya Bakım Kurumlarında Kalan Ayırt Etme Gücü Bulunmayan Kişiler Hakkındaki Hükümleri Ve Türk Hukuku Açısından Değerlendirilmesi’, (2019) LXVIII (1) Ankara Üniversitesi Hukuk Fakültesi Dergisi 213-240.

İmamoğlu S H, 'Vesayet Altındaki Küçüğün Koruma Amacıyla Özgürlüğünün Kısıtlanması (TMK 446)', (2005) LIV (4) Ankara Üniversitesi Hukuk Fakültesi Dergisi 299-342 ('Vesayet Altındaki Küçüğün Korunması').

İsviçre Medeni Kanunu'nun Değiştirilmesine İlişkin 19 Aralık 2008 tarihli Kanun Gerekçesi (Yetişkinlerin Korunması, Kişiler Hukuku, Çocuk Hukuku) BBI 20067003 vd <https://www. admin.ch/opc/de/federal-gazette/2006/7001.pdf> Erişim Tarihi 2 Mayıs 2020.

Kılıçoğlu A M, Aile Hukuku (4. Bası, Turhan 2019).

Kocaağa K, ‘Koruma Amacıyla Özgürlüğün Kısıtlanması', (2006) X (1-2) Gazi Üniversitesi Hukuk Fakültesi Dergisi 33-54. 
Koç N, 'Türk Medenî Kanunundaki Düzenlemeler Işığında Vesayet Hukukuna Genel Bakış', (2005) VII ( ) Dokuz Eylül Üniversitesi Hukuk Fakültesi Dergisi 120-99.

Oğuzman K, Seliçi Ö ve Oktay-Özdemir S, Kişiler Hukuku- Gerçek ve Tüzel kişiler (17. Bası, Filiz 2018).

Oktay-Özdemir, Saibe: 'Ayırt Etme Gücü Bulunmayan Yetişkinlere Yapılacak Tıbbi Müdahalelere Onay Konusunda İsviçre Hukukunda Yapılan Değişiklikler', (2016) XI (145-146) Bahçeşehir Üniversitesi Hukuk Fakültesi Dergisi 223-243.

Öztan B, Aile Hukuku (6. Bas1, Turhan 2015).

Serozan R, Medeni Hukuk-Genel Bölüm-Kişiler Hukuku (8. Bas1, Vedat 2018).

Spirig E, 'Art 397a-397f' in Peter Gauch, Jörg Schmid (eds) Kommentar zum Schweizerischen Zivilgesetzbuch, Das Familienrecht, 3. Abteilung: Die Vormunschaft (Art. 360-456), Band II, Nummer $3 a$ (Schulthess1995)

Tuor P, Schnyder B, Schmid J and Rumo-Jungo A, Das Schweizerische Zivilgesetzbuch (14th edn, Schulthess 2015).

Türk Medeni Kanunu Tasarısı ile Türk Kanunu Medenisinde Değişiklik Yapılması Hak-kında Kanun Tasarısı ve Ankara Milletvekili Yücel Seçkiner'in; Ankara Milletvekili Esvet Özdoğu ve Dört Arkadaşının; Aynı Kanunda Değişiklik Yapılması Hakkında Kanun Teklifleri ve Adalet Komisyonu Raporu (1/611, 1/425, 2/361, 2/680), <https://www.tbmmgov.tr/sirasayi/donem21/ yil01/ss $723 \mathrm{mhtm}>$ Erişim Tarihi 9 Mayıs 2020.

\section{Elektronik Kaynaklar}

http://www.bger.ch

http://www.hudoc.echr.coe.int

http://www.lexpera.comtr 
